\title{
The Role of Isothiocyanates as Cancer Chemo-Preventive, Chemo-Therapeutic and Anti-Melanoma Agents
}

\author{
Melina Mitsiogianni ${ }^{1}$, Georgios Koutsidis ${ }^{1}$, Nikos Mavroudis ${ }^{2}$, Dimitrios T. Trafalis ${ }^{3}{ }^{(1)}$, \\ Sotiris Botaitis ${ }^{4}$, Rodrigo Franco ${ }^{5,6}$, Vasilis Zoumpourlis ${ }^{7}$, Tom Amery ${ }^{8}$, Alex Galanis ${ }^{9}$ (D), \\ Aglaia Pappa ${ }^{9}$ and Mihalis I. Panayiotidis ${ }^{1, *(D)}$ \\ 1 Department of Applied Sciences, Northumbria University, Newcastle Upon Tyne NE1 8ST, UK; \\ melina.mitsiogianni@northumbria.ac.uk (M.M.); georgios.koutsidis@northumbria.ac.uk (G.K.) \\ 2 Department of Food and Nutritional Sciences, University of Reading, Reading RG6 6AP, UK; \\ nikos.mavroudis@reading.ac.uk \\ 3 Laboratory of Pharmacology, Unit of Clinical Pharmacology, Medical School, National and Kapodistrian \\ University of Athens, 11527 Athens, Greece; dtrafal@med.uoa.gr \\ 4 Second Department of Surgery, Democritus University of Thrace, 68100 Alexandroupolis, Greece; \\ smpotait@med.duth.gr \\ 5 Redox Biology Centre, University of Nebraska-Lincoln, Lincoln, NE 68588, USA; rodrigo.franco@unl.edu \\ 6 School of Veterinary Medicine and Biomedical Sciences, University of Nebraska-Lincoln, Lincoln, \\ NE 68583, USA \\ 7 Institute of Biology, Medicinal Chemistry and Biotechnology, National Hellenic Research Foundation, \\ 11635 Athens, Greece; vzub@eie.gr \\ 8 The Watrercress Company/The Wasabi Company, Waddock, Dorchester, Dorset DT2 8QY, UK; \\ tom.amery@thewatercresscompany.com \\ 9 Department of Molecular Biology and Genetics, Democritus University of Thrace, 68100 Alexandroupolis, \\ Greece; agalanis@mbg.duth.gr (A.G.); apappa@mbg.duth.gr (A.P.) \\ * Correspondence: m.panagiotidis@northumbria.ac.uk; Tel.: +44(0)191-227-4503
}

Received: 4 February 2019; Accepted: 12 April 2019; Published: 18 April 2019

\begin{abstract}
Many studies have shown evidence in support of the beneficial effects of phytochemicals in preventing chronic diseases, including cancer. Among such phytochemicals, sulphur-containing compounds (e.g., isothiocyanates (ITCs)) have raised scientific interest by exerting unique chemo-preventive properties against cancer pathogenesis. ITCs are the major biologically active compounds capable of mediating the anticancer effect of cruciferous vegetables. Recently, many studies have shown that a higher intake of cruciferous vegetables is associated with reduced risk of developing various forms of cancers primarily due to a plurality of effects, including (i) metabolic activation and detoxification, (ii) inflammation, (iii) angiogenesis, (iv) metastasis and (v) regulation of the epigenetic machinery. In the context of human malignant melanoma, a number of studies suggest that ITCs can cause cell cycle growth arrest and also induce apoptosis in human malignant melanoma cells. On such basis, ITCs could serve as promising chemo-therapeutic agents that could be used in the clinical setting to potentiate the efficacy of existing therapies.
\end{abstract}

Keywords: isothiocyanates; glucosinolates; chemo-therapy; cruciferous vegetables; skin cancer; malignant melanoma; cell cycle; growth arrest

\section{Introduction}

Nutrition is known to play an important role in human health, primarily in the context of preventing chronic disease development including cancer. As such, it can have a positive impact in health outcomes, 
thus improving quality of life $[1,2]$. Overall, the protective role from consuming plant-derived foods has been documented and well established in numerous studies. In particular, the potential of fruits and vegetables in disease prevention was documented in the case of phytochemicals, the bioactive components of plant-derived foods capable of exhibiting a wide range of biological activities including anti-inflammatory, anti-infectious, anti-oxidant and anti-cancer [3-7]. Furthermore, evidence also shows that these compounds can modulate gene expression through epigenetic mechanisms involving DNA methylation, histone modification and modulation of miRNAs [8,9]. However, their prevailing anti-oxidant capacity is of particular importance given that oxidative stress (and, consequently, accumulation of free radicals) plays a major role in ageing and other chronic diseases, including heart disease, cognitive disorders and cancer. Briefly, an imbalance in the equilibrium of antioxidants and free radicals (of oxygen and/or nitrogen species) can result in DNA damage and genomic instability, thus increasing the risk for disease development and mortality [10-13]. To these ends, phytochemicals have been shown to contribute to the detoxification of the body and thus have a positive impact on human health and disease prevention [13-15]. In the context of cancer chemo-therapy, the use of agents (synthetic, natural or biological) is utilized in order to reverse, suppress or prevent the multi-stage process of carcinogenesis $[16,17]$. On the other hand, natural products possess pleiotropic mechanisms responsible for their health benefits, including prevention of cancer development $[7,14,15]$. Phytochemicals are generally categorized according to their chemical properties and functional groups into carotenoids, phenolics, nitrogen-containing (e.g., alkaloids, amines) and organosulfur compounds (e.g., isothiocyanates and allyl sulphides such as allicin) [18]. Especially, sulfur-containing substances (isothiocyanates (ITCs)) have raised scientific interest with their unique properties in cancer prevention and treatment.

Glucosinolates (GLs) are an important group of phytochemicals abundant in vegetables of the Brassicaceae family, including broccoli, watercress, brussels sprouts, cabbage, horseradish, cauliflower, mustard, etc. [19]. They all share a common core structure consisting of a $\beta$-thioglucosilated moiety linked to a sulfonated aldoxime and a variable aglucone side chain $(\mathrm{R})$, derived from eight selected amino acids (alanine, leucine, isoleucine, valine, phenylalanine, tyrosine, tryptophan and methionine and possibly glutamic acid) [20,21]. According to the amino acid precursors used at the early stages of their biosynthesis, they are mainly categorized as aliphatic, aromatic, heterocyclic (indoles), benzoate, multiple glycosylated and sulfur-containing GLs [22,23].

Their content and type in plants vary between and within the family members [23]. It is mainly dependant on environmental factors like cultivation, climate, region, genotype, the part of the plant and its developmental stage [24-27]. To date, about 130 different GL structures have been identified [28]. However, a more detailed review of the literature led to the characterization of a greater number of structures, thus it is currently considered that the number reaches 200 individual structures [23]. Upon hydrolysis, they give rise to various bioactive compounds, including ITCs, responsible for the health benefits provided through the consumption of these cruciferous vegetables [29,30]. ITCs are compounds characterised by an $\mathrm{R}-\mathrm{N}=\mathrm{C}=\mathrm{S}$ structure, where $\mathrm{R}$ is a variable side chain consisting of alkyl or allyl groups. They are highly reactive electrophiles that interact reversibly with the thiol group of cystine residues to form dithiocarbamates [31].

In general, ITCs are mainly responsible for the flavour and odour of cruciferous vegetables and exert a wide range of bioactivities from defence against pathogens (in Brassica vegetables) for the prevention of cancer development [32]. Among them, their anti-microbial, anti-oxidant and anti-inflammatory properties are of particular importance. More specifically, the anti-microbial activity of ITCs has been documented in a number of studies, suggesting possible use of these compounds as natural antibiotic agents, food additives and/or pesticides [33-39]. It has been reported that they have both bacteriostatic and bactericidal potencies and many mechanisms have been suggested to mediate these properties. Briefly, ITCs exert anti-microbial activities through disruption of the cell membrane, deregulation of enzymatic processes and induction of heat-shock proteins as well as oxidative stress [33]. In addition, ITCs can also act as indirect antioxidants by activating the Nrf2-dependent pathway [40,41]. To this end, a study by McWalter et al., 2004 has shown that ITCs increased the expression of detoxifying 
enzymes in both wild-type mice and mouse cell lines, but not in Nrf2-knockdown ones [42]. Moreover, a microarray-based expression profile analysis revealed Nrf2-mediated elevation of antioxidant proteins and metabolizing enzymes in hepatocellular carcinoma (HepG2) cells treated with wasabi-derived sulforaphane (SFN) and SFN analogues, highlighting the importance of this pathway in inducing an antioxidant response [43]. However, a constitutive activation of this pathway could be potentially advantageous for cancer cells by creating an environment that favours cell survival and growth. In addition, the persistent Nrf2 activity can interfere with the metabolic process of some anti-cancer drugs, leading to chemo-resistance [44-46]. Overall, it seems that although ectopic expression of Nrf2 could be detrimental in fully-developed cancers, its transient activation in healthy individuals can exert a protective effect [47].

Apart from its role in anti-oxidant processes, Nrf2 can also mediate an anti-inflammatory response through the transcriptional factor nuclear factor-kappa B (NF- $\mathrm{kB}$ ) signalling pathway, although the exact mechanism has not yet been elucidated [48-50]. On another note, ITCs can also repress the inflammatory process by inhibiting NF- $\mathrm{KB}$ which, in turn, regulates the expression of pro-inflammatory and anti-apoptotic proteins [51-53]. Moreover, other mechanisms (independent of Nrf2/NF-kB) have also been shown to mediate ITC-induced anti-inflammatory properties including epigenetic alterations [54,55]. For example, it has been shown that SFN suppresses histone deacetylase (HDAC) activity while increasing DNA methyltransferase 1 (DNMT1) expression, thus blocking lipopolysaccharide (LPS)-induced pro-inflammatory cytokine formation in porcine monocyte-derived dendritic cells [55]. Another novel anti-inflammatory role of SFN has been proposed recently, showing that it inhibits the formation of multiple inflammasomes and thus showing an action against inflammasome-originated diseases [56]. Finally, another mechanism involves the binding to the nucleophilic N-terminal proline residue of the macrophage migration inhibitory factor (MIF), thus modifying its structure and preventing its interaction with extracellular receptors and other protein targets. MIF is a pro-inflammatory cytokine with pro-tumourigenic, pro-angiogenic and anti-apoptotic properties. As such, it is involved in various inflammatory diseases, like rheumatoid arthritis and atherosclerosis, in addition to being implicated at different stages of tumour development, including proliferation and angiogenesis [57-59]. Consequently, a number of studies have supported the role of ITCs, especially sulforaphane (SFN), iberin (IBN), allyl-ITC (AITC), benzyl-ITC (BITC) and phenethyl-ITC (PEITC) (Figure 1), in cancer prevention and chemotherapy [60-64], topics which will be discussed in more detail below.

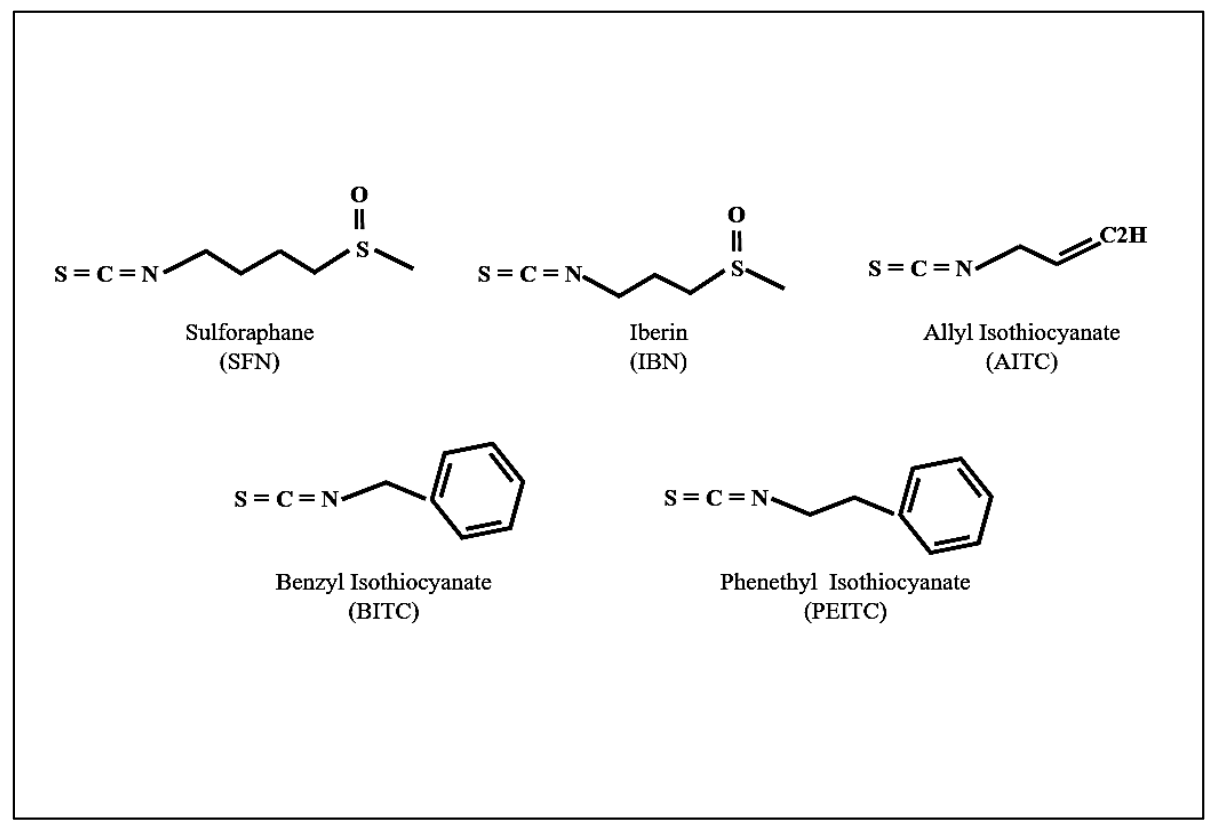

Figure 1. The structures of major isothiocyanates (ITCs). 


\subsection{GLs-Myrosinase System}

GL hydrolysis is catalysed by an enzyme called myrosinase, which was discovered in 1839 by Bussy as a protein necessary for the release of essential oil from mustard seed [65]. Disruption of the plant by chewing or cutting leads to the release of myrosinase, a $\beta$-thioglucosidase, and brings it into contact with their substrates where it breaks down the sulfur group of the glucosidic bond $[21,66]$. It is mainly considered to be located in idioblastic cells (as opposed to GLs which are located in different cells inside the plant), although more studies are needed to elucidate their compartmentalization within plants [67]. For instance, in the model species Arapidopsis thaliana, GLs were found in S-cells (located between the phloem and the endoderm), which are in close proximity to myrosin cells (located at the phloem parenchyma) [67-69]. This compartmentalization acts as a barrier that allows GLs to degrade only when the plant is under stress conditions, such as during a pathogen attack or tissue disruption. Activation of the myrosinase-glucosinolate system (also known as mustard oil bomb) results in the formation of diverse chemically and biologically distinct compounds including thiocyanates, isothiocyanates, nitriles and indoles [32,70,71] (Figure 2). Usually, a 'Lossen'-like rearrangement occurs that promotes formation of ITCs [21,71-73]. At the end of this process, the outcome is largely dependent on various other factors like $\mathrm{pH}$, temperature and availability of ferrous ions, epithiospecifier proteins (ESP), presence of proteins that interact with myrosinase as well as type of GLs [70,74,75]. Other factors that affect the content of GLs (and, consequently, their concentration and intake) include food processing, cultivation, storage and post-harvest processing [76-79]. Moreover, lower ITC levels can be produced by other mechanisms, including hydrolysis of GLs by bacterial myrosinases. For example, in humans, after consumption of cooked vegetables the formation of ITCs is promoted by the microbiome in the intestinal tract after destruction of endogenous myrosinase due to food preparation; however, this process is poor, resulting in a much lower yield of ITCs [71,80]. Once ITCs are formed in the gut, they enter the cell passively where they bind with high affinity and reversibly to glutathione (GSH) leading to their metabolism (and consequently elimination) through the mercapturic acid pathway. Briefly, ITCs are diffused into the blood circulation through the gastrointestinal tract where they conjugate with GSH, a reversible reaction catalyzed by glutathione S-transferases (GSTs). Enzymatic modifications of the GSH moiety take place in the liver with the final N-acetylcysteine-(NAC-)conjugate being produced in the kidneys, where it is actively secreted into the urine $[31,66,70,81]$.

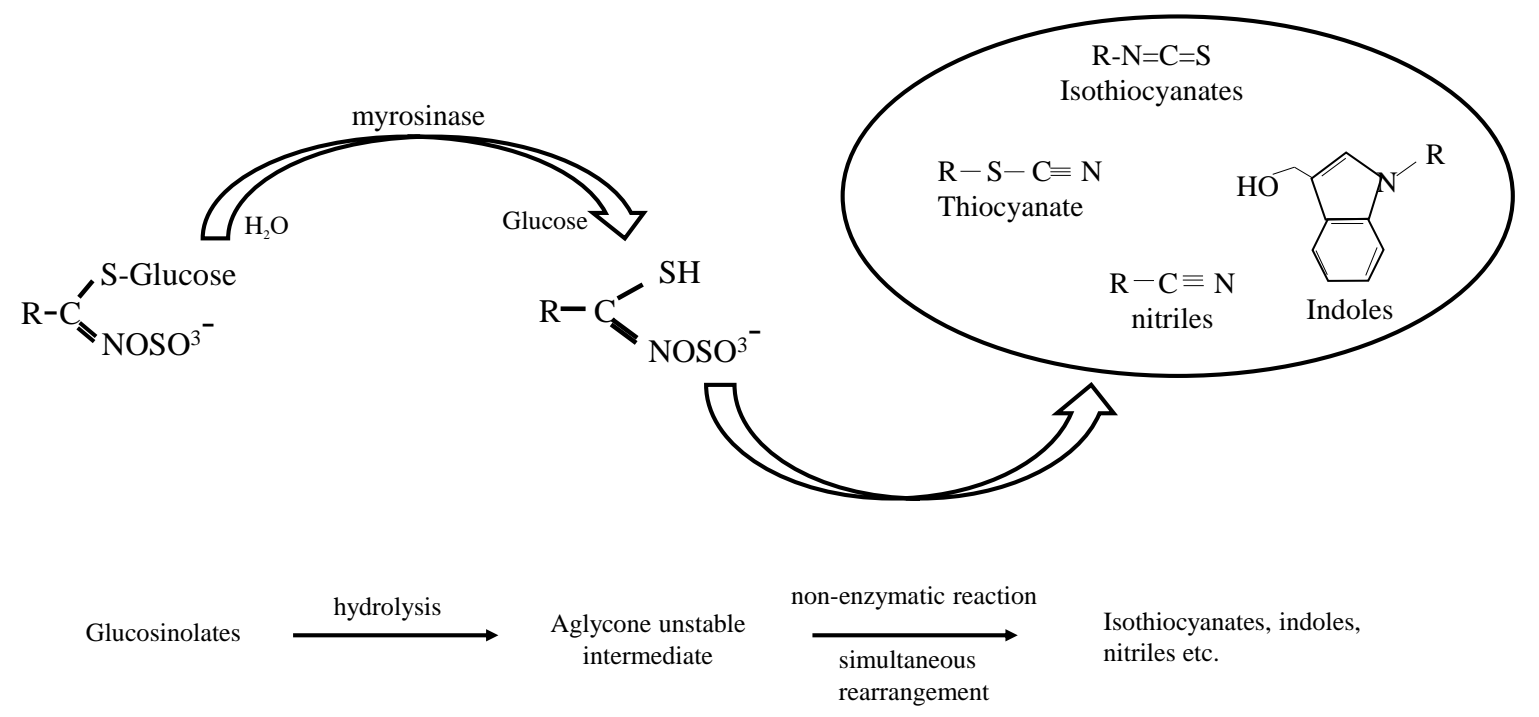

Figure 2. Hydrolysis of glucosinolates by myrosinase.

\subsection{Anti-Cancer Properties}

ITCs exert their anti-tumour activities through various mechanisms, including (i) modulation of phase I and II enzymes, (ii) inhibition of cell growth by causing cell cycle arrest and inducing cell 
death, (iii) prevention of metastasis and angiogenesis and (iv) regulation of the epigenetic machinery (Figure 3).

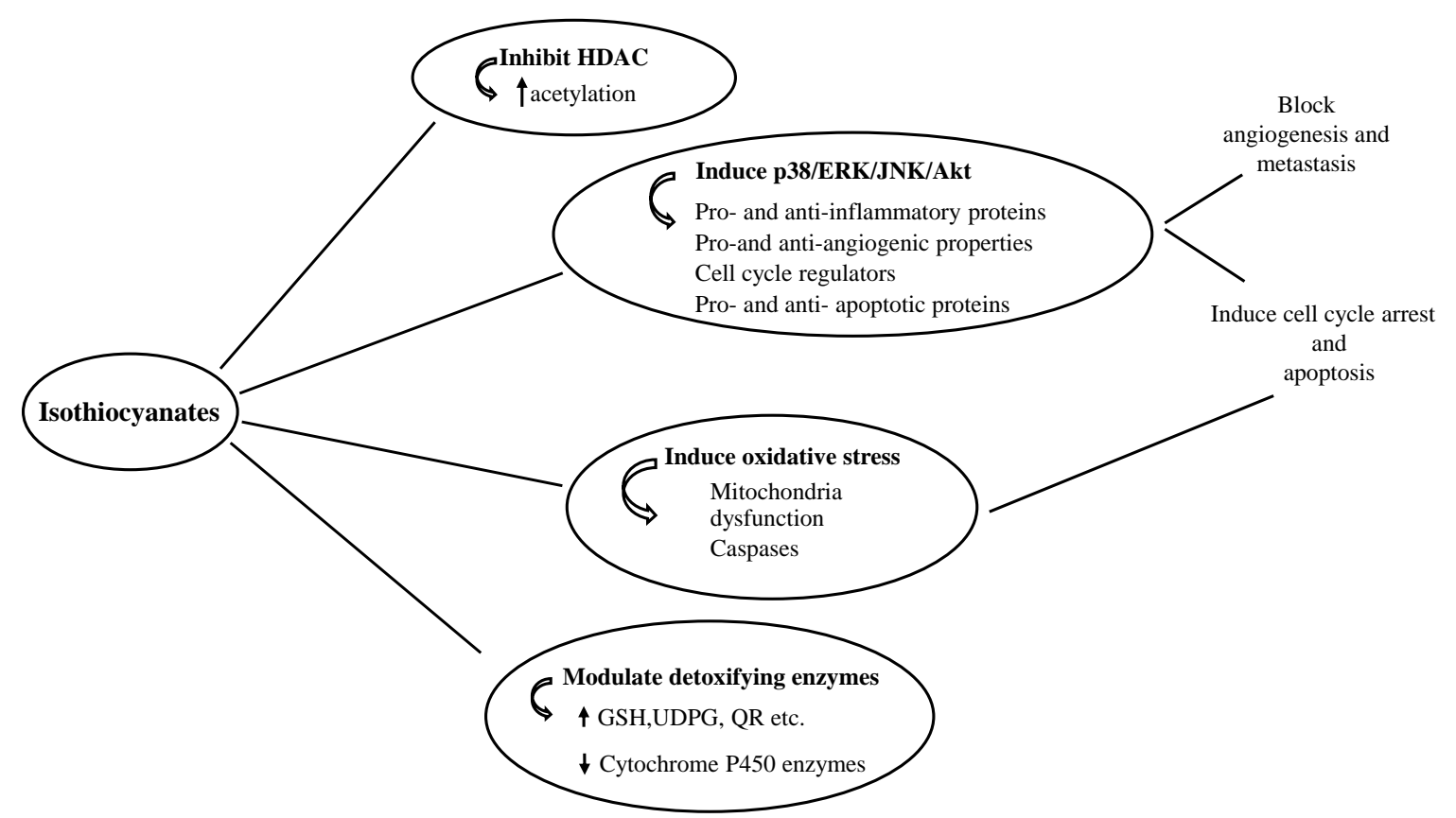

Figure 3. Schematic representation of the proposed molecular pathways targeted by isothiocyanates (ITCs), glutathione (GSH), uridine 5'-diphospho-glucuronosyltransferase (UDPG), quinone reductase $(\mathrm{QR})$.

\subsubsection{Inhibition of Phase I and Induction of Phase II Enzymes}

Phase I and II enzymes are important mediators of the detoxification process in the human body. They interact with various chemicals, such as toxins and carcinogens, playing an important role in their metabolism and excretion from the body. Cytochrome P450 (CYP450) enzymes are the most important phase I enzymes, which either deactivate or, in some cases, activate pro-carcinogens to their active form. On the other hand, phase II enzymes exert a predominantly protective role as their interaction with carcinogens increase their elimination from the body. The most important phase II enzymes are glutathione S-transferases (GSTs), uridine 5'-diphospho-glucuronosyltransferase (UDP)-glucuronosyl transferase, nicotinamide adenine dinucleotide phosphate (NADPH), quinine reductases and glutamate cysteine ligase. In general, it is proposed that ITCs downregulate phase I enzymes to inhibit carcinogen activation, while upregulating phase II enzymes to enhance detoxification and prevent reactive oxygen species (ROS)-induced damage [82,83]. SFN (3 mg/kg and $12 \mathrm{mg} / \mathrm{kg}$ ) has been shown to regulate the activity of CYP2B, CYP3A2 and CYP1A2 enzymes and induce the expression of quinone and glutathione reductase in rats [84]. In line, PEITC $(150 \mu \mathrm{mol} / \mathrm{kg}$ ) increases the expression of UDP-glucuronosyltransferase UGT1A6 (uridine diphosphate glucuronosyltransferase 1 family, polypeptide A6) and also modulates CYP2B15 activity while decreases nicotinamide N-methyltransferase (NNMT) levels in rats [85]. Both BITC and PEITC were found to prevent nicotine (BITC and PEITC at $25 \mu \mathrm{M}$ and $3 \mu \mathrm{M}$ respectively) and tobacco-specific nitrosamine 4-(methylnitrosamino)-1-(3-pyridyl)-1-butanone (NNK) (BITC and PEITC at $1 \mu \mathrm{M}$ and $0.3 \mu \mathrm{M}$, respectively) metabolism by inhibiting the activation of CYP2A6 and CYP2A13, respectively, in an NADPH-dependent manner [86]. Moreover, SFN $(10 \mu \mathrm{M})$ increased the activity of various GSTs (A3, A4, M1, P1 and T1) in order to inactivate aflatoxin B1-8,9-epoxide (AFBO) in alpha mouse liver 12 (AML12) cells [87]. Oral administration of allyl isothiocyanate (AITC) $(40 \mu \mathrm{mol} / \mathrm{kg} / \mathrm{day})$ also increased the activity of both quinone reductase (QR) and GSTs in urinary bladder, thus indicating a reduced risk of bladder cancer after frequent exposure to ITCs [88]. Exposure of primary normal human bronchial 
epithelial cells (NHBE) and lung adenocarcinoma cells (A549) to both broccoli sprout extracts as well as individual ITCs (e.g., SFN, BITC and PEITC) have led to upregulation of GSTP1 (Glutathione S-transferase $\mathrm{P}$ ) and NQO1 (NAD(P)H dehydrogenase [quinone] 1) phase II enzymes [89]. In addition, SFN, ECN (erucin) and IBN (1-12 $\mu \mathrm{M})$ were also found to increase the expression levels of thioredoxin reductase 1 (TrxR1) in human breast cancer (MCF-7) cells [90]. Furthermore, SFN also increased the transcription of UDP-glucuronosyl transferase (UGT) 1A1 as well as glutathione S-transferase A1 (GSTA1) in human hepatoma HepG2 and HT29 cells in a time- and dose-dependent manner [91].

\subsubsection{Cell Cycle Arrest and Cell Death}

The cell cycle consists of four distinct phases: G1, S, G2 and M. Cells go from a resting phase (G0) to proliferation and back to rest. The progression from one phase to the next is mainly regulated by cyclins that form complexes with cyclin-dependent kinases (CDKs) and is inhibited by CDK inhibitors (including p21 and p27) which have a broad affinity for various CDKs. All of these are found deregulated in cancer, thus leading to uncontrolled proliferation of cancer cells [92]. ITCs have been found to induce cell cycle arrest by modulating the expression levels of cell cycle regulators including cyclins and CDKs. Exposure of human colon carcinoma (HT29) cells to SFN (15 $\mu \mathrm{M})$ was shown to increase the accumulation of these cells in the G2/M phase through activation of $p 21$ and $c d c 2$ kinase [93]. A study by Cheng et al., 2016 showed an induced growth arrest in the G2/M phase by inhibiting the expression of Cyclin B1 and disruption of cyclin B1/CDC2 conjugate in cervical cancer cells exposed to SFN $(6.25 \mu \mathrm{M}, 12.5 \mu \mathrm{M}$ and $25 \mu \mathrm{M})$ [94]. Alternatively, cell cycle arrest (in G0/G1 phase) and apoptotic induction were observed in T24 bladder cancer cells exposed to SFN (5-20 $\mu \mathrm{M})$, an effect that was mediated by overexpression of a p27 cyclin-dependent kinase inhibitor [95]. Inhibition of growth (at the G0/G1 phase) through modulation of p53, p21, p17, CDK2 and cyclin E activities was also observed in HSC-3 oral carcinoma cells after exposure to PEITC $(0.5,1,2,2.5$ and $5 \mu \mathrm{M})$ [96]. Cyclin B1, as well as Cdk1, Cdc25B and Cdc25C, expression levels were found to be dramatically decreased in AITC-treated $(20 \mu \mathrm{M})$ prostate cancer cells with a resultant increase in the number of cells in the G2/M phase [97]. In addition, BITC also induced G2/M phase arrest in human pancreatic cancer (Capan-2) [98] and HL-60 cells [99], at concentrations of $20 \mu \mathrm{M}$ and $5 \mu \mathrm{M}$ respectively, by upregulating p21 and also modulating the expression of other regulatory proteins important for cell cycle progression. Moreover, a study by Cheung et al., 2008 assessed the involvement of the p38/MAPK (mitogen-activated protein kinases) pathway in ITC-induced growth suppression. In this work, treatment of HT29 colon cancer cells with an inhibitor specific for $p 38$ activity attenuated the PEITC-induced $(25 \mu \mathrm{M}) \mathrm{G} 1$ arrest, while MAPK activation induced the activity of various other cyclins and, consequently, blocked growth progression [100]. Other studies have also shown that ITCs induced cell cycle arrest in various cancer cell lines, an effect associated mainly with the regulation of the expression levels of p21, GADD45 (growth arrest and DNA damage) and various other cyclins [101-104]. Finally, only recently, it was proposed that the deregulation of the cell cycle may gradually lead to apoptotic induction [93].

\subsubsection{Apoptosis}

Apoptosis is a genetically programmed cell death which is characterized by cell shrinkage, chromatin condensation, DNA fragmentation and formation of apoptotic bodies. The apoptotic process is complex and is regulated by a wide range of proteins including (but not limited to) various caspases, B cell lymphoma 2-family (Bcl2) proteins and the $p 53$ gene. The apoptotic process is deregulated in cancer cells (thus overcoming cell death) and so compounds that can target the induction of molecules involved in the apoptotic process could be of potential benefit as therapeutic agents $[105,106]$. ITCs have been shown to trigger cell death in cancer cells and their role in apoptotic induction has been excessively studied. The mode of action is complex and it seems that there is a cross-talk between signalling pathways that regulate the transcription of various proteins important for the apoptotic process $[62,107,108]$. A study by Yu et al., 1998 showed that exposure of human cervical cancer (HeLa) cells to PEITC (and other structurally related ITCs) $(10 \mu \mathrm{M})$ induced apoptosis, while 
treatment of these cells with a caspase-3 inhibitor attenuated this phenomenon, thus suggesting that the apoptotic process is strongly linked with caspase-3 activity [109]. To date, many more studies have shown that ITCs exert their anti-proliferative effect through diverse regulatory pathways including: (i) Various signal transduction pathways (PI3K/AKT, MAPKs and mTOR (mammalian target of rapamycin) [110,111], (ii) increased production of reactive oxygen species (ROS) [112], (iii) inhibition of heat-shock proteins [113] and (iv) mitochondrial dysfunction [96,108,114]. In another study, Xu et al., 2006 showed that treatment of prostate cancer (PC-3) cells with SFN (5-40 $\mu \mathrm{M})$, PEITC $(2-10 \mu \mathrm{M})$ and AITC $(5-100 \mu \mathrm{M})$ decreased cell viability by inducing apoptosis. More specifically, ERK1/2 (extracellular signal-regulated kinases), JNK1/2 (c-Jun N-terminal kinases), Elk-1 (ETS-like gene 1, tyrosine kinase) and c-Jun phosphorylation levels were significantly increased, resulting in the induction of activator protein $1(A P-1)$, which plays an important role in various processes including cell death [115]. The contribution of EGFR (epidermal growth factor receptor)/PI3K (phosphoinositide 3-kinase)/AKT (protein kinase B) and MAPK pathways in ITC-induced apoptosis and cell cycle growth arrest was also documented in a number of other studies, suggesting the importance of these pathways in ITC-induced cytotoxicity [110,116-119]. On the other hand, modulation in the activity levels of pro-apoptotic (e.g., Bax, Bid and Bak) and anti-apoptotic (e.g., Bcl2 and Bcl-XL) proteins, as well as various other caspases, has been also involved in ITC-induced cell death. Treatment of pancreatic cancer cells with PEITC $(2.5 \mu \mathrm{M}, 5 \mu \mathrm{M}$ and $10 \mu \mathrm{M})$ increased protein levels of Bak while decreased those of $\mathrm{Bcl} 2$ and $\mathrm{Bcl}-\mathrm{XL}$ thus inducing apoptosis [120]. In addition, exposure of Jurkat T-leukaemia cells at $30 \mu \mathrm{M}$ of SFN, resulted in increased Bax and p53 expression levels, which were correlated with an apoptotic induction [121]. Moreover, AITC-induced apoptosis $(7.5 \mu \mathrm{M}, 15 \mu \mathrm{M}$ and $30 \mu \mathrm{M})$ was also found to be dependent on elevated levels of Bax together with decreased levels of Bcl 2 in renal carcinoma cells [122].

\subsubsection{Oxidative Stress}

A number of studies also support that ITCs can inhibit cell survival through increased production of reactive oxygen species (ROS). To this end, high concentrations of SFN $(10 \mu \mathrm{M}$ and $20 \mu \mathrm{M})$ significantly induced ROS generation in the p53-null osteosarcoma (MG-63) cell line by reducing GSH production and recycling, thus contributing to dysfunction of membrane potential and decreased cell survival. It is noteworthy that, although SFN is a well-known antioxidant agent, under this experimental setting, an imbalance between the antioxidant and prooxidant activities was observed, with the antioxidant activity being dependant on the concentration and exposure period of MG-63 cells to SFN [112]. Also, $10 \mu \mathrm{M}$ of SFN triggered the intracellular accumulation of ROS, resulting in significantly increased levels of Nrf2 as well as heme oxygenase-1 (HO-1), and consequently, decreased cell survival of bronchial epithelial cells. Pre-treatment with $\mathrm{N}$-acetylcysteine (NAC) suppressed SFN-induced elevation of Nrf2 and HO-1 levels, suggesting that the observed effect was dependent on the oxidative stress response [123]. In line with these observations, exposure of oral cancer cells to BITC, $(7.5 \mu \mathrm{M})$ and PEITC $(10 \mu \mathrm{M})$ also caused increased production of oxidative stress leading to GSH depletion, increased expression of serine/threonine protein kinase ATM, Chk2, p53, and p21, while expression of Cdc2, cyclin B1, Mcl-1 and Bcl-2 was suppressed. Thus, ROS elevation resulted in DNA damage, mitochondria disruption and, subsequently, induction of cell cycle growth arrest and apoptosis [124,125].

Another mechanism accounting for ITC-induced inhibition of cell proliferation and survival, through elevation of ROS levels, involves the downregulation of specificity protein (Sp) transcription factors and their gene targets. These transcription factors regulate the expression of various genes involved in proliferation, survival, angiogenesis, inflammation and drug resistance. Overexpression of these proteins is a common finding in multiple cancer types and is associated with poor patient prognosis [126-128]. The importance of Sp downregulation has been demonstrated in a recent study where knocking-down Sp1, Sp3 and Sp4 in breast, kidney, pancreatic, lung and colon cancer cell lines reduced cancer cell growth, promoted apoptosis and prevented cell migration and invasion [129]. Recently, BITC and PEITC have been reported to trigger oxidative stress and inhibit proliferation in 
cancer cells, through a ROS-dependent mechanism that involves the downregulation of Sps [130,131]. These observations are consistent with other studies utilizing ROS-inducing agents with anti-cancer properties such as celastrol [132], HDAC inhibitors [133], penfluridol [134], piperlogumine [135], curcumin and other curcuminoids [136,137], CDDO-Me (a synthetic derivative of triterpenoid glycyrrhetinic acid) [138,139] and GT-094 (a nitric oxide-non-steroidal anti-inflammatory drug) [140]. Their mechanism of action is thought to be ROS-dependent, since their effects are abrogated in the presence of GSH, and involves decreased expression of Sps via modulation of the Myc-miR-ZBTB axis. More specifically, it is proposed that ROS induction inhibits the expression of Myc and Myc-associated micro-RNAs (e.g., miR-27a, miR-20a and miR-17-5p) and, consequently, the activation of zing finger and BTB (ZBTB) inhibitors, thus downregulating Sp transcription factors and their targets [126,141]. Overall, it appears that ITCs can modulate the expression of genes in more than one cellular pathway, important for cell proliferation and survival.

\subsubsection{Autophagy}

Autophagy is an essential process for cell survival and maintenance through which cells degrade their damaged and defective cytoplasmic components. It occurs when cells are exposed to several stress stimuli, such as low oxygen, starvation and accumulation of faulty organelles and proteins, among others. In general, under 'housekeeping levels', autophagy promotes cell survival and growth by removing defective and redundant cellular constituents. However, under conditions of diminished apoptosis or induction of high levels of autophagy, it may also promote cell death, either through self-cannibalization or by inducing apoptosis [142,143]. In the context of carcinogenesis, autophagy can play a dual role either as (i) a tumour-suppressor mechanism by scavenging mutated proteins and faulty organelles (thus inhibiting cell transformation), or (ii) as a tumour-progression mechanism by favouring cancer cell survival and proliferation under hypoxic conditions. Given that autophagy is essential in cellular transformation, the discover of agents capable of inhibiting its induction could be of particular importance in cancer therapy [144,145]. Alternatively, its ectopic activation in cancer cells could also serve as a pro-death signal. To this end, other studies have shown that its induction can inhibit cancer cell growth through activation of T cell-dependent immune responses [146,147].

ITC s can act as autophagic inducers and, by doing so, they may exert either a protective role [148-157] or promote cell death [158-162] according to tumour type, stage and genetic context. To this end, a recent study investigated the autophagic involvement on BITC-induced inhibition of cell growth in lung cancer cells and showed an induction of ER (endoplasmatic reticulum) stress-mediated autophagy capable of protecting from the suppressive effects of BITC on cancer cell growth. Pre-treatment of cells with an autophagic inhibitor enhanced the growth inhibitory effect of BITC, supporting the cytoprotective role of autophagic induction [149]. In line with these observations, exposure of prostate cancer cells to BITC also triggered autophagy through mTOR signaling inhibition [150] or ROS-accumulation [151]. Inhibition of autophagy in these experimental models found to enhance BITC-induced apoptosis of prostate cancer cells. Moreover, PEITC anti-metastatic potential reported to be significantly increased after inhibition of autophagy and, subsequently, inactivation of the JAK2 (Janus kinase 2)/STAT3 (signal transducer and activator of transcription 3) pathway in three lung cancer cell lines [152]. In contrast, breast cancer cells exposed to BITC are reported to promote autophagic cell death through increased expression of the FOXO1 (forkhead box protein O1) pathway [158]. Also, exposure of prostate cancer cells to PEITC resulted in increased cell death via Atg5-mediated induction of autophagy and apoptosis. In this experimental setting, the apoptotic induction was attenuated after pharmacological inhibition of autophagy [159]. In line, SFN-NAC (sulforaphane-N-acetyl-cysteine), an important metabolite of SFN, was shown to downregulate $\alpha$-tubulin through induction of autophagy and activation of ERK1/2, leading to cell-cycle arrest and cell growth inhibition in glioma cells [160]. 


\subsubsection{Epigenetic Mechanisms}

ITCs can also exert their anti-tumourigenic properties by interfering with the epigenetic machinery [61], which plays an important role in a number of physiological (e.g., genomic imprinting genomic imprinting [163-165], X-chromosome inactivation [166,167], development of the embryo and placenta [168-170]) as well as disease-modulating processes, including carcinogenesis [171-173]. Within the context of carcinogenesis, changes in DNA methylation patterns, as well as post-translational modifications in histone proteins, result in repressed transcription (i.e., silencing) of tumour suppressor genes and/or activation of proto-oncogenes to oncogenes, among other mechanisms [174-176].

\section{Inhibition of HDACs}

Histone deacetylases (HDACs) are generally associated with condensed chromatin conformation leading to transcriptional repression. To date, HDAC inhibitors have been utilized in the clinical setting and are considered to be therapeutic agents against tumour progression by causing cell cycle arrest, inducing cell death and inhibiting angiogenesis $[177,178]$. To this end, ITCs have been shown to act as potent HDAC inhibitors in various cancer cell lines by inducing genomic alterations resulting in changes in carcinogenic activity of xenobiotics through (i) Nrf2-mediated induction of phase II detoxification enzymes, (ii) induction of cell cycle growth arrest and iii) apoptosis [179-182]. More specifically, PEITC $(10 \mu \mathrm{M})$ was shown to cause cell cycle arrest of prostate cancer cells $(\mathrm{LNCaP})$ by enhancing Histone 3 (H3) acetylation which was shown by chromatin immunoprecipitation (ChIP) to be associated with increased expression of p21, thus suggesting the inhibition of HDACs [182]. In addition, SFN (at $15 \mu \mathrm{M}$ ) was also found to be an efficient HDAC inhibitor in BPH-1 (benign prostatic hyperplasia), LnCaP (lymph node carcinoma of the prostate) and PC-3 (prostate epithelial) cells by triggering growth arrest and apoptotic processes [183]. Also, protein expression and activity levels of HDACs 1, 2 and 3 were shown to be significantly decreased in a number of cancer cells exposed to ITCs [184-186]. Phenylhexyl ITC (PHI), at concentrations between 1-20 $\mu$ M, was found to significantly reduce HDAC1 and HDAC 2 activity, in prostate cancer cells, as well as to enhance the acetylation of histones H3, H4 and H3 lysine [186]. SFN, at $15 \mu \mathrm{M}$, prevented the repair of DNA damage in human colon cancer (HCT116) cells via diminished HDAC activity levels, accompanied with a marked reduction on the expression of HDACs 3 and 6, resulting in decreased C-terminal-binding protein (CtBP)-interacting protein (CtIP) levels, an important mediator of DNA repair capacity, thus inducing cell cycle arrest and apoptosis [180]. Furthermore, SFN decreased HDAC activity, which led to increased p21 and Bax protein expression levels and induced growth arrest in the G2/M phase and apoptosis in murine melanoma (B16) (concentrations ranging between 3-12 $\mu \mathrm{M}$ ), human glioma (U251) $(12 \mu \mathrm{M})$ [179] and human lung cancer (A549) (15 $\mu \mathrm{M})$ cells [187]. A study by Jiang et al., 2016 also showed reduction of tumour growth in the lungs of mice exposed to SFN through inhibition of HDAC activity [187]. Other studies also supported the inhibitory effect of ITCs in HDAC activity in both pancreatic [185] and bladder [184] cancer cells. On the other hand, exposure of human pancreatic cancer cells, at $10 \mu \mathrm{M}$ of BITC, inhibited HDAC1/HDAC3 activity, leading to inactivation of NF- $\kappa$ B and cyclin D1, in vivo and in vitro, thus leading to growth arrest of these cells [185]. Moreover, SFN and erucin (ECN), at $20 \mu \mathrm{M}$, attenuated the phosphorylation of Histone 1 isoforms, an important step in bladder cancer development through inactivation of HDACs 1, 2, 4 and 6 [184].

Interestingly, a study by Myzac et al., 2004 was the first to report on the inhibitory effect of SFN on HDACs [188]. In fact, in this study, it was documented that two conjugated compounds of SFN metabolism [SFN-Cys (cysteine)and SFN-NAC (N-acetylcysteine conjugate)] were responsible for the inhibition of HDAC activity and not the parent compound itself. This observation was confirmed by pre-treating cells with a GST inhibitor, thus impairing the first step of the mercapturic acid metabolic pathway of SFN and consequently the production of its major metabolites. Also, treatment of cells with SFN, SFN-GSH, SFN-Cys or SFN-NAC showed that only the two metabolites could effectively inhibit HDACs, while SFN and SFN-GSH had no significant inhibitory activity in vitro [188]. Between the two metabolites, SFN-Cys was found to be the more potent inhibitor. In fact, the order of such inhibition 
efficiency was documented to be as follows: SFN $=$ SFN-GSH $<$ SFN-NAC $<$ SFN-Cys. Furthermore, by utilizing molecular modeling methodologies, it was revealed that SFN-Cys's inhibitory capacity was via direct interaction with HDACs, suggesting its potential role as a competitive inhibitor. To this end, it was shown that the $\alpha$-amino group of SFN-Cys fits into the enzyme pocket and its carboxylate group creates a ligand with the zinc atom within the active site of the ezyme $[188,189]$. These insights into how SFN-conjugates bind and consequently suppress HDACs have led to the identification of other structurally related ITCs like sulforaphene, phenylbutyl isothiocyanate, phenethyl isothiocyanate and erucin, among others $[189,190]$.

\section{Inhibition of DNMTs}

DNA methylation results in the addition of methyl groups in cytosine residues of $\mathrm{CpG}$ dinucleotide regions that are dispersed across the genome [191,192]. The transfer of these methyl groups is utilized by DNA methyltransferases (DNMTs) with the most important ones being DNMTs 1, 3A and 3B [193,194]. Both hypo- and hyper-methylation have been observed to enhance the expression of oncogenes while inhibiting that of tumour suppressor genes, respectively [195]. ITCs have been shown to cause changes in DNMT expression patterns, thus leading to differential expression of genes capable of mediating the carcinogenic process [196].

In prostate cancer cells, SFN suppressed the expression of DNMT1 and DNMT3A thus decreasing cell proliferation $[197,198]$. To this end, it has been proposed that SFN-induced inhibition of DNMT1 is associated with HDAC suppression, which can lead to decreased histone deacetylation leading to re-expression of $p 21$ and impairment of DNMT1 activation [196]. Phenylhexyl isothiocyanate (PHI) (ranging between 5 and $40 \mu \mathrm{M}$ ) was also found to reduce the activity of DNMT1 and 3B (thus causing the re-expression of the $\mathrm{p} 15$ tumour suppressor gene), in addition to causing an increased acetylation of histones H3 and H4 in leukaemic T cells [199]. In general, it has been demonstrated that ITCs are epigenetic agents with dual activity on the epigenome, by inhibiting both DNA hyper-methylation and histone deacetylation $[181,200,201]$. To this end, SFN at $2.5 \mu \mathrm{M}$ and $5 \mu \mathrm{M}$ has been shown to induce Nrf2-dependent inhibition of skin tumour transformation in mouse JB6 cells by decreasing the expression of DNMT1, DNMT3A and DNMT3B, as well as that of HDACs 1, 2, 3 and 4 [181]. Similarly, SFN at $1 \mu \mathrm{M}$ and $2.5 \mu \mathrm{M}$, decreased Nrf2 promoter methylation and histone deacetylation, both events leading to an increase in N-ribosyldihydronicotinamide quinone reductase (NQO)-1 transcription in prostate cancer cells [200]. SFN-treated human breast cancer cells (5 $\mu \mathrm{M}$ and $10 \mu \mathrm{M})$ underwent apoptosis mediated by downregulating the expression and activity of DNMT1 and DNMT3A, thereby repressing the activation of the human telomerase reverse transcriptase ( $h T E R T)$ gene commonly overexpressed in many cancers [202]. On the other hand, in estrogen receptor (ER)-negative breast cancer cells exposed to $10 \mu \mathrm{M}$ of SFN-suppressed protein, expression levels of HDACs and DNMTs both contributed to decreased cell viability, suggesting its usage as a therapeutic agent for the treatment of patients with ER-negative breast cancer [201]. Finally, Ras-association domain family 1 isoform $\mathrm{A}($ RASSF1A) is a tumour suppressor gene found downregulated in a number of cancers. Exposure to $5 \mu \mathrm{M}$ PEITC restored $R A S S F 1 A$ expression levels and decreased viability levels by inhibiting the activity levels of DNMT1 DNMT3A and DNMT3B, as well as those of HDACs 1, 2, 4 and 6 [203].

\section{Modulation of miRNAs}

mi-RNAs are functional non-coding RNAs 20-24 nucleotides long that play a critical role in regulating various physiological processes; they are also implicated in disease development, including cancer. Various mi-RNAs such as miR-155 and miR-21 are deregulated during carcinogenesis, promoting tumour development and progression [204]. Many studies have shown that ITCs exert their effect by regulating the epigenetic machinery through targeting of specific miRNAs in cancer. For instance, when epithelial colon (NCM460 and NCM356) cell lines were exposed to $10 \mu \mathrm{M} \mathrm{SFN}$ and IBN, upregulation of miR-23b, miR-27b (tumour suppressors) together with downregulation of miR-155 were evident, thus suggesting their contribution in chemo-prevention [205]. Prostate cancer 
(PC3) cells exposed to $2.5 \mu \mathrm{M}$ PEITC overexpress miR-194, which decreases expression of matrix metalloproteinases (MMPs) and blocks the invasion capacity of these cells [206]. In non-small cell lung cancer (NSCLC), miR-616-5p is overexpressed and, consequently, promotes tumour progression and metastasis. In this experimental setting, exposure to $5 \mu \mathrm{M} \mathrm{SFN}$ inhibits growth and migration of non-small cell lung cancer cells by downregulating miR-616-5p [207]. Moreover, combinational treatment of SFN with temozolomide (TMZ) enhanced TMZ's potential for apoptotic induction by suppressing miR-21 expression [208]. In bladder cancer cells, epithelial-to-mesenchymal transition (EMT) inhibition by SFN $(2.5 \mu \mathrm{M}, 5 \mu \mathrm{M}, 10 \mu \mathrm{M})$ was partly due to the upregulation of miR-200c, resulting in the suppression of Cyclooxygenase (COX-2) and MMP2 and MMP9, which are important for cellular migration [209]. Finally, in prostate cancer, androgen receptor $(A R)$ activity is important for initiation and progression. In this context, PEITC $(10-20 \mu \mathrm{M})$ blocked AR transcriptional activity by decreasing miR-141 together with increasing miR-17 expression, followed also by an induction of small heterodimer partner (shp) activity (a repressor of AR) and suppression of p300/CBP (CREB-binding protein)-associated factor (PCAF) (co-regulator of AR) respectively [210,211].

\subsubsection{Anti-Angiogenic and Anti-Metastatic Properties}

New vascularization is an important step in tumour progression by supporting increasing demands for nutrients and oxygen and thus contributes to growth, invasion and metastasis [212]. Metastasis is a complex process, characterized by the loss of cellular adhesion, increased invasiveness, entry to circulation, colonization and proliferation into new tissue. The metastatic process is mainly mediated by genes that play an important role in the modification in the interaction of cells with extracellular matrix and angiogenesis. Among them, MMPs are of significant importance by mediating the extracellular matrix (ECM) degradation, thus promoting cell migration and angiogenesis. Although many MMPs are found overexpressed during carcinogenesis and angiogenesis, MMP-2 and -9 are the most extensively characterized ones [213]. On the other hand, angiogenesis occurs in six sequential steps, i.e., vascular destabilization, extracellular matrix degradation, migration and proliferation of endothelial cells, tube formation and vascular stabilization. The process is regulated by a number of molecules that include MMPs, plasminogen activators (PAs) and integrins among others. The most studied pro-angiogenic factor is vascular endothelial growth factor (VEGF). An imbalance between angiogenic factors and angiogenesis inhibitors play a pivotal role in carcinogenesis [214,215].

Many studies have tried to elucidate the mechanism of the anti-angiogenic and anti-metastatic capacity of ITCs. In general, it has been proposed that ITCs regulate the expression of important genes that control a wide range of cellular processes, including cell cycle arrest, cell death, angiogenesis, cell migration, etc., through modulation of various signalling cascades like p38/MAPK and mTOR pathways [216-218]. To these ends, exposure of human umbilical vein endothelial (HUVECs) cells to 5 $\mu \mathrm{g} / \mathrm{mL}$ AITC and PITC downregulated VEGF and various pro-inflammatory cytokines (e.g., IL-1 $\beta$, IL-6, TNF-alpha), while upregulating IL-2 and tissue inhibitor of metalloproteinases (TIMP), thus preventing migration, invasion and tube formation [218]. Similarly, $4 \mu \mathrm{M}$ PEITC was found to suppress the secretion of VEGF, downregulate VEGF receptor 2 protein levels and inactivate the prosurvival serine-threonine kinase Akt, thus preventing new vascularization in HUVECs [219]. BITC, at $2 \mu \mathrm{M}$ and $5 \mu \mathrm{M}$, was also shown to be effective in inhibiting new capillary formation and invasion of human glioma cells as well as causing G2/M arrest by regulating the expression of molecules important for cell cycle progression (cyclin B1 and p21) and the neo-angiogenetic process (MMPs-2 and -9 and vascular endothelial cadherin (VE-cadherin). Furthermore, modulation in the expression of tumour suppressor (miR-144, miR-122) as well as oncogenic (miR-181b, miR-9) mi-RNAs also was observed following the BITC treatment, suggesting involvement of post-translational modifications in the anti-angiogenic properties of BITC [216].

Hypoxia promotes tumour progression, maintenance and metastasis by stimulating angiogenesis. Thus, hypoxia-induced angiogenesis is related to hypoxia inducible factor- $1 \alpha$ (HIF- $1 \alpha$ ) expression, which in turn stimulates VEGF-induced vascular remodelling and is partially regulated by the mTOR 
signalling pathway [214,220]. In an experimental setting of hypoxia-exposed human colon and gastric cancer cells, exposure to SFN, at concentrations ranging between 12.5 and $50 \mu \mathrm{M}$, dramatically decreased HIF-1 $\alpha$ and VEGF protein levels, as well as hypoxia-induced migration [221]. Similar results were observed when breast $(6.5-26 \mu \mathrm{M})$ and renal $(5-40 \mu \mathrm{M})$ cancer cells were exposed to PEITC under hypoxic conditions (i.e., suppressing HIF- $1 \alpha$ and VEGF protein levels) [222]. In turn, VEGF inhibition leads to a decreased expression profile of other proteins also associated with the vascularisation process. Overall, PEITC-induced inhibition of angiogenesis was found to be PI3K/AKT and ERK/MAPK dependent suggesting an important role of these signalling pathways in the angiogenetic process [223].

The epithelial-to-mesenchymal transition (EMT) is a developmental process of epithelial cell transformation characterized by loss of polarity and adhesion and an enhancement of migratory and invasive properties. The process is regulated by various molecules (e.g., E-cadherin, vimentin, MMPs) and pathways (e.g., Wnt and Notch) [224,225]. Inhibition of EMT by SFN, in thyroid cancer cells, has been associated with modulations in the activity of major signalling pathways (PI3K/Akt and p38/ERK/JNK/MAPK) and depends on ROS production in vitro $(20-40 \mu \mathrm{M})$ and in vivo $(50 \mathrm{mg} / \mathrm{kg}$ ). Molecules that contribute to EMT process such as E-cadherin and MMP-2 and -9 were also downregulated after exposure to SFN [226]. BITC also was able to repress EMT partially through Forkhead Box Q1 (FOXQ1) suppression in both breast cancer cells $(2.5 \mu \mathrm{M}$ and $5 \mu \mathrm{M})$ and xenografts (7.5 $\mu \mathrm{mol}$ BITC/mouse), thus reducing their metastatic potential [227]. Finally, another study indicated that VEGF suppression was mediated through inhibition of the Forkhead Box O1 (FOXO1)/AKT pathway as well [228]. In another set of experiments, the anti-metastatic potential of AITC $(5 \mu \mathrm{M}$ and $10 \mu \mathrm{M}$ ) was evident after inactivation of the MAPK signalling pathway and downregulation of MMPs-2 and -9 in human colorectal adenocarcinoma (HT-29) cells [217]. Furthermore, exposure of these cells to $0.01-10 \mu \mathrm{M}$ BITC inhibited their growth in a dose-dependent manner and altered their metastatic potential by reducing the expression levels of MMP2 and MMP9 and (urokinase-type plasminogen activator (u-PA) [229]. On the other hand, 10-15 $\mu \mathrm{M}$ SFN was also shown to act as an anti-angiogenic agent through its capacity to supress endothelial cell proliferation, impair cellular microtubule polymerization and decrease the expression levels of various metastatic markers (e.g., HIF1 $\alpha$, MMP-2, VEGF) in human endothelial cells [230,231]. In vivo studies, utilizing Balb/C mice implanted with VEGF-impregnated matrigel plugs, further support the anti-angiogenic activity of SFN (100 nmol/day, intravenously for seven days) since it decreased VEGF-induced vascularization [230].

\section{ITCs as Cancer Chemo-Preventive and Chemo-Therapeutic Agents}

\subsection{ITCs as Cancer Chemo-Preventive Agents: Human Studies}

Over the last decades, ITCs have raised scientific interest as agents capable of preventing cancer development $[63,232-237]$, though such protective effects might depend on the individual's genetic variation in (glutathione S -transferase) GST genes, given their important role in the metabolism and excretion of ITCs as well as in the inactivation of xenobiotics [238-240]. Thus, a reduced activity of these enzymes is associated with a longer exposure of tissues to ITCs, which significantly decreases the risk of disease. Therefore, people with inherited two null variants of the glutathione S-transferase $\mathrm{Mu} 1$ (GSTM1) and glutathione S-transferase theta 1 (GSTT1) alleles are more resistant to cancer development due to longer exposure to ITCs [241-243]. However, current studies support the association between GST-null polymorphism with an increased risk of cancer [244-246] while others suggest that there is no association between cancer risk and GSTs polymorphisms [247,248]. Consequently, it is obvious that the influence of GST genotype on cancer susceptibility is still ill defined as a result of many inconsistent and contradictory studies in this field of research.

However, epidemiological evidence supports the hypothesis that a diet high in cruciferous vegetables can gradually reduce the risk of cancer development. An inverse correlation between cruciferous vegetables consumption and risk of pancreatic cancer was reported in a case-control study that included 390 prostate cancer cases and 414 controls in urban Shanghai [249]. In another 
case-control study, a protective effect of cruciferous vegetable consumption was documented against colorectal cancer risk in women from Shanghai (322 cases and 1251 controls), which was associated with GSTM1- and GSTT1-null polymorphisms [250]. A study by Zhao et al., 2007 also showed that a diet rich in cruciferous vegetables decreased the risk of bladder cancer development. In this case-control study, 694 newly diagnosed patients and 708 controls participated and found that the highest consumption of cruciferous vegetables was related to a $29 \%$ decreased risk for bladder cancer development [239]. Furthermore, in another case-control study of 1619 prostate cancer patients and 1618 controls (African-Americans, Caucasian, Japanese and Chinese men), it was shown that an inverse association exists between cruciferous vegetable consumption and prostate cancer development [251]. Other case-control studies have shown that higher dietary intakes of cruciferous vegetables can decrease the risk of lung cancer, especially squamous and small cell lung carcinomas [252]. For instance, a case-control study of 420 Chinese women showed that a diet rich in ITCs led to a decreased rate of lung cancer incidence, especially in smokers [243]. Moreover, a 32\% reduction in the risk of lung cancer was observed in individuals who consumed three or more weekly servings of cruciferous vegetables compared to those consuming one-half servings or less (meta-analysis of $\beta$-carotene and retinol efficacy trial (CARET) trial conducted in 14,120 participants) [253]. Several other case-control studies also support a beneficial effect of dietary ITCs in breast cancer. More specifically, studies in Caucasian (740 cases and 810 controls) and Chinese (337 cases and 337 controls) women found that cruciferous vegetables intake was significantly lower in women diagnosed with breast cancer than women in control groups [254,255]. Finally, there are several more case-control studies associated with low intake of cruciferous vegetables and higher risk of developing various types of cancer [256-258]. On the other hand, no significant association was observed between cruciferous vegetable consumption and risk for liver cancer in a study of 217 patients and 42 corresponding controls in Shanghai [259]. In addition, no significant association was reported between low cruciferous vegetable consumption and lung cancer susceptibility among smoking women (209 incident lung cancer cases and 787 individually matched non-smoking controls) although a meta-analysis showed an association between urinary ITC levels, GSTM1 genotype and lung cancer risk [260]. These observations contradict with previous studies, although the majority of research outcomes suggest that there is an inverse relationship between intake of ITCs derived from cruciferous vegetables and the overall incidence for various types of cancer development.

\subsection{ITCs as Cancer Chemo-Therapeutic Agents: Animal Studies}

\subsubsection{In Vitro Studies Utilizing Various ITCs}

In a human breast adenocarcinoma cell model, exposure of cells to AITC $(5,10,15$ and $20 \mu \mathrm{M})$ induced generation of oxidative stress as well as the ERK signalling pathway, both of which resulted in activation of apoptosis (e.g., increased expression of caspase-3 and -9), growth arrest of cells in the G2/M phase (e.g., increased expression of p21 and suppression of cyclin B and CDK1), mitochondrial depolarization and deregulation of mitochondrial-associated proteins (e.g., decreased expression of Bcl-2 and increased expression of cytochrome $c$ and Apaf-1) [111]. In line with these observations, a study by Wu et al., 2011 reported elevated ROS levels that led to an increase in nitric oxide (NO) production, deregulation of mitochondria potential, cell cycle suppression and apoptosis in osteogenic sarcoma cells exposed to BITC $(7.5 \mu \mathrm{M})$ and PEITC $(10 \mu \mathrm{M})$ [261]. In a breast cancer cell model consisting of MDA-MB-231 and MCF-7 cells, exposure of cells to BITC (2.5-20 $\mu \mathrm{M}$ ) resulted in a significant decrease of cell viability mediated by ROS production, mitochondrial dysfunction, deregulation of proand anti-apoptotic genes and activation of various caspases [262]. In addition, PEITC $(0.5-5 \mu \mathrm{M})$ was found to be an effective inhibitor of oral squamous carcinoma cell growth through cell cycle arrest and mitochondrial-dependent apoptosis due to ROS production and $\mathrm{Ca}^{2+}$ accumulation [96]. On the other hand, AITC $(1-40 \mu \mathrm{M})$ induced a dose-dependent inhibition of the survival of human A549 and H1299 non-small cell lung cancer (NSCLC) cells by inducing replication stress as well as sensitizing tumour 
cells to radiation [263]. Moreover, it has been shown that even low doses of PEITC $(0.1-10 \mu \mathrm{M})$ were able to block cell growth and proliferation of prostate cancer (LNCaP) cells [264]. Finally, exposure of human colon cancer cell lines to SFN and PEITC $(0.1-100 \mu \mathrm{M})$ have led to a dose-dependent inhibition of their proliferation as well as apoptotic induction [265].

Exposure to PHI $(5-40 \mu \mathrm{M})$ blocked cell cycle progression in human leukaemia cells through perturbations in acetylated as well as methylated states of chromatin histones [266]. In comparison, in human embryonic kidney 293 cells and human colorectal cancer (HCT116) cells, exposure to SFN $(15 \mu \mathrm{M})$ caused a decrease in HDAC-3 and -6 activity levels while raising p21 expression levels suggesting that SFN could act as an effective tumour-suppressor agent [188,267]. SFN $(15 \mu \mathrm{M})$ was also found to be an efficient HDAC inhibitor in BPH-1, LnCaP and PC-3 prostate epithelial cells resulting in triggering of growth arrest and induction of the apoptotic process as well [183]. Furthermore, in prostate cancer, GSTP1 methylation is known to play an important role in tumour initiation. In this context, PEITC $(0.5-20 \mu \mathrm{M})$ was found to suppress the deacetylation and methylation of the GSTP1 gene and thus block the carcinogenic process [268].

Exposure of prostate cancer cells to PEITC $(5 \mu \mathrm{M}$ and $7.5 \mu \mathrm{M})$ and SFN $(20 \mu \mathrm{M}$ and $30 \mu \mathrm{M})$ significantly inhibited phosphorylation of IKK/I $\kappa B$ kinases and $\mathrm{p} 65$ as well as NFKB subunit nuclear translocation, thus suppressing the expression of NFKB-related genes (e.g., VEGF, cylcin D1 and B-cell lymphoma-extra large (Bcl-XL) leading to disturbing angiogenesis and invasion [269]. Alternatively, the signal transducer and activator of transcription 3 (STAT3) factor is found to be overexpressed in various cancers where it favours tumour growth and progression. A study by Boreddy et al., 2011 has shown that BITC $(5-20 \mu \mathrm{M})$ inhibited the phosphorylation of STAT3 in pancreatic cancer cell lines followed by a decrease in VEGF and MMP-2 expression, thus blocking angiogenesis [270].

In addition, it was proposed that ITCs protect against tumourigenesis by enhancing the ubiquitination process of oncogenes, thus favouring their degradation by the proteasome. In fact, both BITC and PEITC have been shown to target USP9x (ubiquitin specific peptidase 9 X-linked), a member of deubiquitinating enzymes (DUB), thus promoting the anti-apoptotic protein Mcl-1 (myeloid cell leukaemia-1) and the oncogenic fusion protein Bcr-Abl for degradation in various tumourigenic cell lines [271]. Finally, another target of ITCs' anti-proliferative effect is tubulin, which is known to disrupt microtubule polymerization and, consequently, induce mitotic arrest and apoptosis [272-274]. Thus, it becomes evident that a number of studies support the plurality of effects of ITCs in various cancers including ovarian [275], glioma [276], bladder [277], breast [278,279], myeloma [280], prostate [281-283] and colon [284].

\subsubsection{In Vivo Studies Utilizing Various ITCs}

Oral administration of AITC in the form of mustard seed powder $(9 \mu \mathrm{mol} / \mathrm{kg}$ or $90 \mu \mathrm{mol} / \mathrm{kg}$ body weight, once daily for three weeks) significantly prevented tumour development in mouse bladders and invasion in muscles by triggering cell cycle arrest and apoptosis while inhibiting angiogenesis [285]. At the same time, BITC ( $5 \mathrm{mg} / \mathrm{kg}$ and $10 \mathrm{mg} / \mathrm{kg}$ body weight, every day for 19 weeks) suppressed the development of prostate cancer in a transgenic mouse adenocarcinoma model by inducing cell cycle arrest. Moreover, BITC resulted in reduced Ki67 (a proliferation marker), cyclin A, cyclin D1 and CDK2 expression in the prostatic tissue [286]. A study by Srivastava et al., 2003 also demonstrated that injection of $10 \mu \mathrm{M}$ AITC three times per week significantly inhibited the growth of PC-3 xenografts in vivo by inducing apoptosis, thereby decreasing the proportion of cells undergoing mitosis [287]. SFN (at an average daily dose of $7.5 \mu \mathrm{mol}$ per animal for 21 days) also decreased prostate cancer cell proliferation in xenografts by suppressing HDAC activity. A reduction in HDAC activity was also observed in the peripheral blood mononuclear cells of healthy humans after consumption of broccoli sprouts (a single dose of $68 \mathrm{~g}$ broccoli sprouts, approximately $105 \mathrm{mg}$ SFN; equivalent to approximately $570 \mathrm{~g}$ of mature broccoli) [288]. Intraperitoneal administration of SFN in nude mice $(25 \mathrm{mg} / \mathrm{kg}, 50 \mathrm{mg} / \mathrm{kg}$ or $100 \mathrm{mg} / \mathrm{kg}$, 3 times/week) injected with lung adenocarcinoma (LTEP-A2) cells significantly decreased cell proliferation and thus tumour progression [289]. Moreover, $5 \mu \mathrm{M} \mathrm{SFN}$ 
and PEITC found to significantly reduce the formation of colonic aberrant and multicrypt foci in F344 rats [290]. Also, mice inoculated with pancreatic cancer (BxPC-3) cells and then orally treated with $12 \mu \mathrm{M}$ BITC showed 43\% less tumour growth (in comparison to control mice) through repression of PI3K, AKT, PDK1, mTOR, FOXO1 and FOXO3a, in addition to an increased apoptotic induction [291].

On another note, a study by $\mathrm{Xu}$ et al., 2006 also described that topical application of $100 \mathrm{nmol}$ of SFN once a day was capable of suppressing 7,12-dimethylbenz(a)anthracene (DMBA)/12O-tetradecanoylphorbol-13-acetate (TPA)-induced skin tumourigenesis, in C57BL/6 mice, an effect which was mediated by Nrf2 [292]. Microarray-based identification of gene expression patterns in the liver of both wild-type and Nrf2 knock-out C57BL/6J mice exposed to SFN (90 mg/kg administered orally) revealed that SFN induced Nrf2 activity. This, in turn, regulates the expression of various other proteins, like phase II detoxifying enzymes (e.g., HO-1, GSTs), cell cycle and growth associated proteins (cyclins, growth factors), heat-shock proteins (e.g., Hsp90) and various kinases (e.g., PI3K, MEKs) thus confirming previous observations on ITC-induced Nrf2 activity [293]. PEITC ( $12 \mu \mathrm{mol} /$ day, 5 days/week) was also found to inhibit tumour formation in human pancreatic cancer (MIAPaca2) cell line xenograft mice [120]. In bladder cancer, both SFN and ECN $(295 \mu \mathrm{mol} / \mathrm{kg}$ orally once a day) were found to significantly block HDAC activation in vivo [184].

Finally, the anti-angiogenic and anti-metastatic effects of ITCs have been also demonstrated in vivo. More specifically, oral administration of $12 \mu \mathrm{M}$ BITC suppressed new vessel formation and suppressed pancreatic tumour growth in mice through inhibition of STAT3 phosphorylation. The tumours collected from mice were characterized by decreased expression of angiogenesis-related proteins, including HIF- $\alpha$, VEGF, MMP-2 [270]. On the other hand, oral administration of $10 \mu \mathrm{M}$ PEITC in MDA-MB-231-BR xenografts prevented the growth of tumour and enhanced the survival of xenografts compared to controls, while the expression levels of VEGF were downregulated in the tumour-bearing mice [294]. In addition, oral administration of $50 \mu \mathrm{mol} / \mathrm{kg}$ or $150 \mu \mathrm{mol} / \mathrm{kg}$ of PEITC inhibited capillary formation and attenuated tumour invasiveness in a chemically induced murine breast cancer model [295].

\section{ITCs as Anti-Melanoma Agents}

Malignant melanoma is a highly aggressive and metastatic type of skin cancer with adverse prognosis, high mortality rates and a poor response to current therapeutic strategies. Its incidence is multifactorial. The most important risk factor for melanoma development is exposure to UV (ultraviolet) radiation by means of prolonged exposure to solar energy and/or frequent use of tanning beds. Other factors that increase the likelihood of disease development include innate predisposition and inheritable traits including fair skin, sun sensitivity and/or a large number of moles [296]. The aggressive nature of melanoma is associated with the accumulation of mutations that activate oncogenes (e.g., $B R A F, N R A S$ ), while inactivating tumour suppressor genes (e.g., phosphatase and tensin homolog; PTEN) [297]. Overall, the molecular pathways that regulate the expression of these genes are constituently activated in melanoma. More specifically, the most important pathways found to be overexpressed include p38/JNK/ERK/MAPK, PI3Kinase/Akt/mTor, $\beta$-catenin and Wnt. Deregulation of proteins important for cell cycle progression and apoptosis also account for the increased survival and proliferation of melanoma cells. Anti-apoptotic proteins such as Bcl-2 and Bcl-xL are overexpressed, while pro-apoptotic modulators such as Bax, Apaf-1 and p53 are suppressed in melanoma. Angiogenesis also plays an important role in melanoma progression and metastasis, thus molecules capable of targeting genes related to both of these processes may be part of an effective anti-melanoma strategy $[298,299]$. Finally, epigenetic modifications in pathways controlling cell growth, proliferation, motility and apoptosis have also recently been identified in malignant melanoma cells [300].

The anti-carcinogenic effect of ITCs in malignant melanoma has been studied by utilizing both in vitro and in vivo models. In general, ITCs were found to be able to induce growth arrest and apoptosis [301] and also inhibit metastasis [302,303] through induction of various signal transduction 
pathways, generation of oxidative stress and disruption of mitochondrial function, all of which are important mediators of cell growth and proliferation [296].

\subsection{In Vitro Studies Utilizing Various ITCs}

The anti-melanoma effect of ITCs has been studied by utilizing in vitro models of both human and murine species. In murine (B16F-10) melanoma cells, activation of multiple caspases, pro- and anti-apoptotic proteins and pro-inflammatory cytokines (e.g., TNF- $\alpha$, interleukin-1 $\beta$, IL-6, IL-12p40 and NF- $k B$ ) were all shown to be involved in SFN-induced apoptosis $(1-5 \mu \mathrm{M})$ [304]. Furthermore, exposure of these cells to $1-5 \mu \mathrm{g} / \mathrm{mL}$ AITC and PITC depleted the expression and secretion of agents that favour blood vessel formation (e.g., TNF- $\alpha$ and NO) [305]. Such anti-angiogenic capacity was also exerted by AITC and PITC in B16F-10 melanoma cells through decreased expression of VEGF at $5 \mu \mathrm{g} / \mathrm{mL}$ [216]. Moreover, the expression of platelet-activating factor receptor (PAF-R) is linked to a higher metastatic potential in melanoma cells. Exposure to 5-50 $\mu \mathrm{M}$ BITC significantly increased apoptotic cell death in murine PAF-R positive-cells in contrast to PAF-R negative B16F10 cells, suggesting selectivity of BITC towards PAF-R, which is promising for a better management of PAF-R-positive melanoma patients. The apoptotic process was found to be mediated by elevated ROS production and caspase3/7-like activity [306]. In line, another study by Lai et al., 2017 also supported the anti-metastatic potential of BITC and PEITC $(1 \mu \mathrm{M}, 2.5 \mu \mathrm{M}$ and $5 \mu \mathrm{M})$ in B16F-10 cells by showing that both ITCs decreased cell viability, mobility, migration and invasion via inhibition of MMP-2 activity and impaired expression of important metastasis-related proteins like MAPK signalling-associated proteins (e.g., p-ERK1/2, p-p38 and p-JNK1/2), RhoA, Ras, SOS-1, FAK, GRB2, TIMP and NF-kB [307]. Similarly, BITC (0.5 $\mu \mathrm{M}$, $1 \mu \mathrm{M}$ and $2 \mu \mathrm{M})$ and PEITC $(1 \mu \mathrm{M}, 2 \mu \mathrm{M}$ and $2.5 \mu \mathrm{M})$ also prevented human melanoma A375.S2 cell migration and invasion through inhibition of MMP-2 activity as well as via affecting the MAPK signalling pathway [308]. Treatment with SFN at $20 \mu \mathrm{M}$ has been shown to decrease cell survival through activation of p38 and p53, which regulate the expression of pro-apoptotic proteins, such as Bak and PUMA, in both Bowes and SK-Mel-28 human melanoma cells [309]. In addition, exposure of human malignant melanoma (A375) cells to 0.1-5 $\mathrm{MM}$ SFN, BITC and PEITC exerted a cytotoxic effect via multiple apoptotic pathways (intrinsic, extrinsic and endoplasmic reticulum-based), as shown by the increased activity of various caspases indicative of such differential activation [310]. A study by Huang et al., 2012 also showed that addition of PEITC at concentrations of 5-15 $\mu \mathrm{M}$ inhibited the growth of A375.S2 cells by causing G2/M-dependent cell cycle arrest and inducing the intrinsic apoptotic pathway through ROS-mediated mitochondrial dysfunction [301]. Similarly, exposure of A375.S2 melanoma cells to 5-20 $\mu \mathrm{M}$ BITC decreased cell growth and survival in a dose-dependent manner. BITC promoted ROS accumulation in cells and caused changes in the expression of various cyclins and CDKs (e.g., cyclin A, CDK1, CDC25), proteins of the B-cell lymphoma 2 (BCL2) family and various caspases [311]. In line with these observations, $5 \mu \mathrm{M}$ of SFN, BITC and PEITC have also been documented to induce G2/M cell cycle arrest by affecting the expression levels of various cell-cycle regulators in human malignant melanoma (A375) cells [312]. Moreover, the effect of AITC on lysine acetylation and methylation marks on histones $\mathrm{H} 3$ and $\mathrm{H} 4$ have been explored recently. To this end, exposure of A375 cells to $10 \mu \mathrm{M}$ of AITC decreased HDAC and histone acetyl transferase (HAT) activities, while also affecting the acetylated and methylated content of histones (by means of assessing specific lysine modifications), suggesting that AITC can exert an epigenetically-induced anti-melanoma activity [313].

ITCs were also found to affect TRPA (transient receptor potential) ion channels in melanoma cells, which are responsible for calcium efflux in various types of skin cells and are involved in both physiological (e.g., epidermal homeostasis, sensory function) and pathological (e.g., melanoma) processes. For example, although TRPM1 (transient receptor potential cation channel subfamily M member 1 ) is expressed in melanocytes mediating melanin production in melanoma, TRPA1 promotes tumour progression and invasiveness and is linked to a more aggressive disease phenotype [314]. Furthermore, TRPA1 was found to be functionally expressed in various human malignant melanoma 
cell lines but, at the same time, was not critical for an impaired proliferation caused after exposure of these cells to AITC (25-400 $\mu \mathrm{M})$ [315].

On the other hand, oil extracted from the roots and seeds of the plant Eruca sativa (rocket salad; a member of Cruciferous family) has been reported to exert an anti-melanoma activity. Exposure of B16F10 murine and MDA-MB-435 human melanoma cell lines to $20-100 \mu \mathrm{g} / \mathrm{mL}$ of the extract (major components were ECN, SFN, AITC, 3-butenyl-ITC and 2-phenylethyl-ITC) significantly inhibited cell proliferation [316]. Also, combinational treatment of AITC, PEITC and SFN (3-50 $\mu \mathrm{M})$ was found to be a more potent inhibitor of B16F-10 proliferation than the seed oil extract itself [317]. Finally, ITCs decreased proliferation in melanoma stem cells (MSCs), a subgroup of malignant melanoma cells with high metastatic and invasive capacity. MSCs express Ezh2 polycomb group protein that plays an important role in cell survival and which was shown to be suppressed after exposure to 1-20 $\mu \mathrm{M}$ SFN, thereby reducing cell viability, migration and invasion in these cells [318]. However, it was recently reported that the various biological effects of SFN can be attenuated from the presence of other biological factors, in vivo (e.g., the nerve growth factor, etc.), suggesting that a better understanding in the interaction of these compounds with other elements in the body is crucial in order to determine their in vivo efficacy [319].

\subsection{In Vivo Studies Utilizing Various ITCs}

The cytotoxic effect of ITCs has been shown in a number of malignant melanoma animal models. To this end, a study by Bansal et al., 2015 documented that a combinational treatment consisting of allyl isothiocyanate, phenylethyl isothiocyanate and sulphoraphane (at 1:1:1 ratio; $10 \mu \mathrm{M}$ ) decreased tumour growth, volume and weight in C57BL/6 mice injected with B16F-10 melanoma cells and that such a combination was more potent than treatment with naturally occurring Eruca sativa seed oil alone [320]. Intraperitoneal injection of $20 \mathrm{mg} / \mathrm{kg}$ and $40 \mathrm{mg} / \mathrm{kg}$ PEITC as well as $20 \mathrm{mg} / \mathrm{kg}$ BITC significantly decreased the size and weight of tumours in BALB/c mice injected with A375.S2 cells, suggesting that both agents can be effective in melanoma chemotherapy [321,322]. The anti-metastatic potential of both AITC and PEITC has been shown to be linked with inhibition of angiogenesis. More specifically, in C57BL/6 mice inoculated with B16F-10 melanoma cells, capillary formation was prevented after exposure to AITC and PITC ( $25 \mu \mathrm{g} /$ dose/animal/day), an effect which was mediated by reduction in the expression levels of NO and TNF- $\alpha$, both of which promote capillary formation [305]. In another study, exposure to AITC and PITC intraperitoneally at a dose of $1.1 \mathrm{mg} / \mathrm{kg}$ also inhibited the B16F-10-induced metastasis in the lungs of C57BL/6 mice [323]. In line with these observations, SFN (administered intraperitoneally at a dose of $500 \mu \mathrm{g} / \mathrm{dose} / \mathrm{animal} / \mathrm{day}$ ) also blocked the metastatic potential of B16F-10 cells inoculated in C57BL/6 by inducing a cell-mediated immune response and triggering the expression of IL-2 and IFN-gamma, while suppressing those of IL-1beta, IL-6, TNF-alpha and GM-CSF (granulocyte-macrophage colony-stimulating factor) [324]. Moreover, SFN (3.5 mg/kg body weight, injected thrice a week) inhibited cell proliferation and migration in B16F10 xenografts, effects which were both mediated by a reduction in the expression levels of MMP-9 [325]. Additionally, ITCs were also shown to play a role in melanoma epigenetic therapy. More specifically, SFN inhibited growth and proliferation of B16 and S91 murine melanoma cells by downregulating deacetylation enzymes and intraperitoneal injections of SFN-encapsulated microspheres $(500 \mu \mathrm{mol} / \mathrm{kg})$ enhanced its anti-cancer activity in melanoma tumour-bearing C57BL/6 mice [326]. Also, the effect of SFN in Ezh2 stem cell survival protein was assessed after oral administration in mice inoculated with A375 melanoma cancer stem cell (MCS) cells. SFN (10 $\mathrm{mol} / \mathrm{kg}$ body weight; three times per week) inhibited tumour growth, an effect which was associated with reduced expression levels of matrix metalloproteinases, increased expression levels of TIMP3 (Metalloproteinase inhibitor 3) and enhanced apoptosis [318]. Based on our current knowledge of ITCs' effectiveness in melanoma prevention, synthetic analogues (with longer side chains with selenium substituting the sulphur group) have been produced and shown to be effective in inhibiting melanoma survival by regulating signalling pathways like the Akt3 pathway, but without affecting normal cells [327-329]. For instance, naphthalimide is 
one such ITC synthetic analogue that has been found to exert cytotoxicity in both in vivo and in vitro experimental settings [330].

\section{Conclusions}

ITCs are potent electrophiles derived from the breakdown process of GLs, which are abundant in cruciferous vegetables. They are currently considered as an important class of nutraceuticals, characterized by a wide range of properties (e.g., anti-bacterial, anti-inflammatory, anti-cancer) suggesting their possible use in various industries ranging from food to medicine to clinical practice. Their potential application in cancer prevention strategies have posed greater interest over the last years. According to various studies, the consumption of cruciferous vegetables has been associated with a reduced risk of cancer development, thus supporting their protective role. In addition to their protective role, a large body of evidence shows the anti-tumourigenic action of ITCs against different types of cancer both in vitro and in vivo. The observed tumour-inhibitory effects of ITCs have been shown to be mediated through modulation of various cancer-related critical pathways (e.g., enzymatic detoxification, apoptotic induction, oxidative stress generation, signal transduction, epigenetic induction, etc.) and they seem to be more potent against cancer than normal cells. The most important and well characterized pathway associated with the protective effect of ITCs is the Nrf2 pathway, which is associated with the detoxification and elimination of carcinogens from the body. However, various studies have shown its constitutive expression could lead to resistance in chemotherapy. Despite that fact, the overwhelming majority of studies support the protective role of these agents which (together with their low toxicity profile) makes them excellent chemotherapeutic candidates against tumour initiation and progression. However, further studies are needed in order to determine the optimum dose-response and time-course of ITCs, as these parameters can be a significant limitation for their long-term usage in cancer therapeutic interventions.

Melanoma is a highly aggressive type of skin cancer being linked with high mortality rates due to its high metastatic potential and treatment resistance. As such, the disease does not always respond to current therapeutic approaches, largely due to the development of multi-drug resistance. Thus, it is imperative that new potent chemotherapeutic agents are developed for disease management. To this end, ITCs have been studied for their anti-melanoma efficacy by means of interfering with various pathways including inhibition of cell growth and proliferation in both in vitro and in vivo experimental models.

Author Contributions: Conceptualization, M.M., and M.I.P.; methodology, M.M., and M.I.P.; writing一original draft preparation, M.M., G.K., N.M., D.T.T., S.B., R.F., V.Z., T.A., A.G., A.P. and M.I.P.; writing-review and editing, M.M., G.K., N.M., D.T.T., S.B., R.F., V.Z., T.A., A.G., A.P. and M.I.P.; supervision, M.I.P.

Funding: This research received no external funding.

Acknowledgments: The authors acknowledge support from Northumbria University at Newcastle, UK and specifically the Multidisciplinary Research Theme (MDRT) in Bio-economy (MP \& MM).

Conflicts of Interest: The authors declare no conflict of interest.

\section{References}

1. Slawson, D.L.; Fitzgerald, N.; Morgan, K.T. Position of the Academy of Nutrition and Dietetics: The role of nutrition in health promotion and chronic disease prevention. J. Acad. Nutr. Diet. 2013, 113, 972-979. [CrossRef] [PubMed]

2. Russo, G.L. Ins and outs of dietary phytochemicals in cancer chemoprevention. Biochem. Pharmacol. 2007, 74, 533-544. [CrossRef] [PubMed]

3. Fitsiou, E.; Anestopoulos, I.; Chlichlia, K.; Galanis, A.; Kourkoutas, I.; Panayiotidis, M.I.; Pappa, A. Antioxidant and Antiproliferative Properties of the Essential Oils of Satureja thymbra and Satureja parnassica and their Major Constituents. Anticancer Res. 2016, 36, 5757-5763. [CrossRef] [PubMed]

4. Johnson, I.T. Phytochemicals and cancer. Proc. Nutr. Soc. 2007, 66, 207-215. [CrossRef] 
5. Li, A.-N.; Li, S.; Zhang, Y.-J.; Xu, X.-R.; Chen, Y.-M.; Li, H.-B. Resources and biological activities of natural polyphenols. Nutrients 2014, 6, 6020-6047. [CrossRef]

6. Nohynek, L.J.; Alakomi, H.-L.; Kähkönen, M.P.; Heinonen, M.; Helander, I.M.; Oksman-Caldentey, K.-M.; Puupponen-Pimiä, R.H. Berry phenolics: Antimicrobial properties and mechanisms of action against severe human pathogens. Nutr. Cancer 2006, 54, 18-32. [CrossRef]

7. Issa, A.Y.; Volate, S.R.; Wargovich, M.J. The role of phytochemicals in inhibition of cancer and inflammation: New directions and perspectives. J. Food Compost. Anal. 2006, 19, 405-419. [CrossRef]

8. Rupasinghe, H.P.; Sekhon-Loodu, S.; Mantso, T.; Panayiotidis, M.I. Phytochemicals in regulating fatty acid beta-oxidation: Potential underlying mechanisms and their involvement in obesity and weight loss. Pharmacol. Ther. 2016, 165, 153-163. [CrossRef]

9. Supic, G.; Jagodic, M.; Magic, Z. Epigenetics: A new link between nutrition and cancer. Nutr. Cancer 2013, 65, 781-792. [CrossRef] [PubMed]

10. Garcia-Garcia, A.; Rodriguez-Rocha, H.; Madayiputhiya, N.; Pappa, A.; Panayiotidis, M.I.; Franco, R. Biomarkers of protein oxidation in human disease. Curr. Mol. Med. 2012, 12, 681-697. [CrossRef]

11. Panayiotidis, M. Reactive oxygen species (ROS) in multistage carcinogenesis. Cancer Lett. 2008, 266, 3-5. [CrossRef] [PubMed]

12. Nowsheen, S.; Wukovich, R.L.; Aziz, K.; Kalogerinis, P.T.; Richardson, C.C.; Panayiotidis, M.I.; Bonner, W.M.; Sedelnikova, O.A.; Georgakilas, A.G. Accumulation of oxidatively induced clustered DNA lesions in human tumor tissues. Mutat. Res. 2009, 674, 131-136. [CrossRef] [PubMed]

13. Franco, R.; Sanchez-Olea, R.; Reyes-Reyes, E.M.; Panayiotidis, M.I. Environmental toxicity, oxidative stress and apoptosis: Menage a trois. Mutat. Res. 2009, 674, 3-22. [CrossRef] [PubMed]

14. Di Domenico, F.; Foppoli, C.; Coccia, R.; Perluigi, M. Antioxidants in cervical cancer: Chemopreventive and chemotherapeutic effects of polyphenols. Biochim. Biophys. Acta 2012, 1822, 737-747. [CrossRef] [PubMed]

15. Ziech, D.; Anestopoulos, I.; Hanafi, R.; Voulgaridou, G.P.; Franco, R.; Georgakilas, A.G.; Pappa, A.; Panayiotidis, M.I. Pleiotrophic effects of natural products in ROS-induced carcinogenesis: The role of plant-derived natural products in oral cancer chemoprevention. Cancer Lett. 2012, 327, 16-25. [CrossRef] [PubMed]

16. Weng, C.-J.; Yen, G.-C. Chemopreventive effects of dietary phytochemicals against cancer invasion and metastasis: Phenolic acids, monophenol, polyphenol, and their derivatives. Cancer Treat. Rev. 2012, 38, $76-87$. [CrossRef]

17. Kang, N.J.; Shin, S.H.; Lee, H.J.; Lee, K.W. Polyphenols as small molecular inhibitors of signaling cascades in carcinogenesis. Pharmacol. Ther. 2011, 130, 310-324. [CrossRef] [PubMed]

18. Liu, R.H. Potential synergy of phytochemicals in cancer prevention: Mechanism of action. J. Nutr. 2004, 134, 3479S-3485S. [CrossRef]

19. Verkerk, R.; Schreiner, M.; Krumbein, A.; Ciska, E.; Holst, B.; Rowland, I.; De Schrijver, R.; Hansen, M.; Gerhäuser, C.; Mithen, R. Glucosinolates in Brassica vegetables: The influence of the food supply chain on intake, bioavailability and human health. Mol. Nutr. Food Res. 2009, 53, S219. [CrossRef]

20. Kliebenstein, D.J.; Kroymann, J.; Mitchell-Olds, T. The glucosinolate-myrosinase system in an ecological and evolutionary context. Curr. Opin. Plant Biol. 2005, 8, 264-271. [CrossRef]

21. Agerbirk, N.; Olsen, C.E. Glucosinolate structures in evolution. Phytochemistry 2012, 77, 16-45. [CrossRef] [PubMed]

22. Fahey, J.W.; Zalcmann, A.T.; Talalay, P. The chemical diversity and distribution of glucosinolates and isothiocyanates among plants. Phytochemistry 2001, 56, 5-51. [CrossRef]

23. Clarke, D.B. Glucosinolates, structures and analysis in food. Anal. Methods 2010, 2, 310-325. [CrossRef]

24. Śmiechowska, A.; Bartoszek, A.; Namieśnik, J. Determination of Glucosinolates and Their Decomposition Products-Indoles and Isothiocyanates in Cruciferous Vegetables. Crit. Rev. Anal. Chem. 2010, 40, $202-216$. [CrossRef]

25. Velasco, P.; Cartea, M.E.; González, C.; Vilar, M.; Ordás, A. Factors affecting the glucosinolate content of kale (Brassica oleracea acephala group). J. Agric. Food Chem. 2007, 55, 955-962. [CrossRef] [PubMed]

26. Charron, C.S.; Saxton, A.M.; Sams, C.E. Relationship of climate and genotype to seasonal variation in the glucosinolate-myrosinase system. I. Glucosinolate content in ten cultivars of Brassica oleracea grown in fall and spring seasons. J. Sci. Food Agric. 2005, 85, 671-681. [CrossRef] 
27. Kliebenstein, D.J.; Kroymann, J.; Brown, P.; Figuth, A.; Pedersen, D.; Gershenzon, J.; Mitchell-Olds, T. Genetic control of natural variation in Arabidopsis glucosinolate accumulation. Plant Physiol. 2001, 126, 811-825. [CrossRef]

28. Fabre, N.; Poinsot, V.; Debrauwer, L.; Vigor, C.; Tulliez, J.; Fourasté, I.; Moulis, C. Characterisation of glucosinolates using electrospray ion trap and electrospray quadrupole time-of-flight mass spectrometry. Phytochem. Anal. 2007, 18, 306-319. [CrossRef] [PubMed]

29. Wagner, A.E.; Terschluesen, A.M.; Rimbach, G. Health promoting effects of brassica-derived phytochemicals: From chemopreventive and anti-inflammatory activities to epigenetic regulation. Oxid. Med. Cell. Longev. 2013, 2013, 964539. [CrossRef]

30. Dinkova-Kostova, A.T.; Kostov, R.V. Glucosinolates and isothiocyanates in health and disease. Trends Mol. Med. 2012, 18, 337-347. [CrossRef] [PubMed]

31. Zhang, Y. The molecular basis that unifies the metabolism, cellular uptake and chemopreventive activities of dietary isothiocyanates. Carcinogenesis 2012, 33, 2-9. [CrossRef]

32. Grubb, C.D.; Abel, S. Glucosinolate metabolism and its control. Trends Plant Sci. 2006, 11, 89-100. [CrossRef]

33. Dufour, V.; Stahl, M.; Baysse, C. The antibacterial properties of isothiocyanates. Microbiology 2015, 161, 229-243. [CrossRef] [PubMed]

34. Kaiser, S.J.; Mutters, N.T.; Blessing, B.; Günther, F. Natural isothiocyanates express antimicrobial activity against developing and mature biofilms of Pseudomonas aeruginosa. Fitoterapia 2017, 119, 57-63. [CrossRef]

35. Ko, M.-O.; Kim, M.-B.; Lim, S.-B. Relationship between Chemical Structure and Antimicrobial Activities of Isothiocyanates from Cruciferous Vegetables against Oral Pathogens. J. Microbiol. Biotechnol. 2016, 26, 2036-2042. [CrossRef]

36. Wilson, A.E.; Bergaentzlé, M.; Bindler, F.; Marchioni, E.; Lintz, A.; Ennahar, S. In vitro efficacies of various isothiocyanates from cruciferous vegetables as antimicrobial agents against foodborne pathogens and spoilage bacteria. Food Control 2013, 30, 318-324. [CrossRef]

37. Borges, A.; Simões, L.C.; Saavedra, M.J.; Simões, M. The action of selected isothiocyanates on bacterial biofilm prevention and control. Int. Biodeterior. Biodegrad. 2014, 86, 25-33. [CrossRef]

38. Manyes, L.; Luciano, F.B.; Mañes, J.; Meca, G. In vitro antifungal activity of allyl isothiocyanate (AITC) against Aspergillus parasiticus and Penicillium expansum and evaluation of the AITC estimated daily intake. Food Chem. Toxicol. 2015, 83, 293-299. [CrossRef]

39. Freitas, E.; Aires, A.; Rosa, E.; Saavedra, M.J. Antibacterial activity and synergistic effect between watercress extracts, 2-phenylethyl isothiocyanate and antibiotics against 11 isolates of Escherichia coli from clinical and animal source. Lett. Appl. Microbiol. 2013, 57, 266-273.

40. De Figueiredo, S.M.; Binda, N.S.; Nogueira-Machado, J.A.; Vieira-Filho, S.A.; Caligiorne, R.B. The antioxidant properties of organosulfur compounds (sulforaphane). Recent Pat. Endocr. Metab. Immune Drug Discov. 2015, 9, 24-39. [CrossRef]

41. Fuentes, F.; Paredes-Gonzalez, X.; Kong, A.-N.T. Dietary glucosinolates sulforaphane, phenethyl isothiocyanate, indole-3-carbinol/3, 3'-diindolylmethane: Antioxidative stress/inflammation, Nrf2, epigenetics/epigenomics and in vivo cancer chemopreventive efficacy. Curr. Pharmacol. Rep. 2015, 1, 179-196. [CrossRef]

42. McWalter, G.K.; Higgins, L.G.; McLellan, L.I.; Henderson, C.J.; Song, L.; Thornalley, P.J.; Itoh, K.; Yamamoto, M.; Hayes, J.D. Transcription factor Nrf2 is essential for induction of NAD (P) H: Quinone oxidoreductase 1, glutathione S-transferases, and glutamate cysteine ligase by broccoli seeds and isothiocyanates. J. Nutr. 2004, 134, 3499S-3506S. [CrossRef]

43. Trio, P.Z.; Kawahara, A.; Tanigawa, S.; Sakao, K.; Hou, D.-X. DNA Microarray Profiling Highlights Nrf2-Mediated Chemoprevention Targeted by Wasabi-Derived Isothiocyanates in HepG2 Cells. Nutr. Cancer 2017, 69, 105-116. [CrossRef]

44. No, J.H.; Kim, Y.-B.; Song, Y.S. Targeting Nrf2 Signaling to Combat Chemoresistance. J. Cancer Prev. 2014, 19, 111-117. [CrossRef]

45. Jaramillo, M.C.; Zhang, D.D. The emerging role of the Nrf2-Keap1 signaling pathway in cancer. Genes Dev. 2013, 27, 2179-2191. [CrossRef]

46. Furfaro, A.; Traverso, N.; Domenicotti, C.; Piras, S.; Moretta, L.; Marinari, U.; Pronzato, M.; Nitti, M. The Nrf2/HO-1 axis in cancer cell growth and chemoresistance. Oxid. Med. Cell. Longev. 2016, 2016, 1958174. [CrossRef] 
47. Catanzaro, E.; Calcabrini, C.; Turrini, E.; Sestili, P.; Fimognari, C. Nrf2: A potential therapeutic target for naturally occurring anticancer drugs? Expert Opin. Ther. Targets 2017, 21, 781-793. [CrossRef]

48. Cuadrado, A.; Martin-Moldes, Z.; Ye, J.; Lastres-Becker, I. Transcription factors NRF2 and NF-kB are coordinated effectors of the Rho family, GTP-binding protein RAC1 during inflammation. J. Biol. Chem. 2014, 289, 15244-15258. [CrossRef]

49. Li, W.; Guo, Y.; Zhang, C.; Wu, R.; Yang, A.Y.; Gaspar, J.; Kong, A.-N.T. Dietary phytochemicals and cancer chemoprevention: A perspective on oxidative stress, inflammation, and epigenetics. Chem. Res. Toxicol. 2016, 29, 2071-2095. [CrossRef]

50. Li, W.; Khor, T.O.; Xu, C.; Shen, G.; Jeong, W.S.; Yu, S.; Kong, A.N. Activation of Nrf2-antioxidant signaling attenuates NFkappaB-inflammatory response and elicits apoptosis. Biochem. Pharmacol. 2008, 76, 1485-1489. [CrossRef]

51. Surh, Y.-J.; Na, H.-K. NF-kB and Nrf2 as prime molecular targets for chemoprevention and cytoprotection with anti-inflammatory and antioxidant phytochemicals. Genes Nutr. 2008, 2, 313-317. [CrossRef]

52. Shan, Y.; Lin, N.; Yang, X.; Tan, J.; Zhao, R.; Dong, S.; Wang, S. Sulphoraphane inhibited the expressions of intercellular adhesion molecule-1 and vascular cell adhesion molecule-1 through MyD88-dependent toll-like receptor-4 pathway in cultured endothelial cells. Nutr. Metab. Cardiovasc. Dis. 2012, 22, 215-222. [CrossRef]

53. Wagner, A.E.; Boesch-Saadatmandi, C.; Dose, J.; Schultheiss, G.; Rimbach, G. Anti-inflammatory potential of allyl-isothiocyanate-role of Nrf2, NF-кB and microRNA-155. J. Cell. Mol. Med. 2012, 16, 836-843. [CrossRef]

54. Yang, Q.; Proll, M.J.; Salilew-Wondim, D.; Zhang, R.; Tesfaye, D.; Fan, H.; Cinar, M.U.; Grosse-Brinkhaus, C.; Tholen, E.; Islam, M.A.; et al. LPS-induced expression of CD14 in the TRIF pathway is epigenetically regulated by sulforaphane in porcine pulmonary alveolar macrophages. Innate Immun. 2016, 22, 682-695. [CrossRef]

55. Qu, X.; Pröll, M.; Neuhoff, C.; Zhang, R.; Cinar, M.U.; Hossain, M.M.; Tesfaye, D.; Große-Brinkhaus, C.; Salilew-Wondim, D.; Tholen, E. Sulforaphane epigenetically regulates innate immune responses of porcine monocyte-derived dendritic cells induced with lipopolysaccharide. PLoS ONE 2015, 10, e0121574. [CrossRef]

56. Greaney, A.J.; Maier, N.K.; Leppla, S.H.; Moayeri, M. Sulforaphane inhibits multiple inflammasomes through an Nrf2-independent mechanism. J. Leukoc. Biol. 2016, 99, 189-199. [CrossRef]

57. Spencer, E.S.; Dale, E.J.; Gommans, A.L.; Rutledge, M.T.; Vo, C.T.; Nakatani, Y.; Gamble, A.B.; Smith, R.A.J.; Wilbanks, S.M.; Hampton, M.B.; et al. Multiple binding modes of isothiocyanates that inhibit macrophage migration inhibitory factor. Eur. J. Med. Chem. 2015, 93, 501-510. [CrossRef]

58. Crichlow, G.V.; Fan, C.; Keeler, C.; Hodsdon, M.; Lolis, E.J. Structural interactions dictate the kinetics of macrophage migration inhibitory factor inhibition by different cancer-preventive isothiocyanates. Biochemistry 2012, 51, 7506-7514. [CrossRef]

59. Tyndall, J.D.; Lue, H.; Rutledge, M.T.; Bernhagen, J.; Hampton, M.B.; Wilbanks, S.M. Macrophage migration inhibitory factor covalently complexed with phenethyl isothiocyanate. Acta Crystallogr. Sect. F Struct. Biol. Cryst. Commun. 2012, 68, 999-1002. [CrossRef]

60. Gupta, P.; Kim, B.; Kim, S.H.; Srivastava, S.K. Molecular targets of isothiocyanates in cancer: Recent advances. Mol. Nutr. Food Res. 2014, 58, 1685-1707. [CrossRef]

61. Navarro, S.L.; Li, F.; Lampe, J.W. Mechanisms of action of isothiocyanates in cancer chemoprevention: An update. Food Funct. 2011, 2, 579-587. [CrossRef]

62. Wu, X.; Zhou, Q.-H.; Xu, K. Are isothiocyanates potential anti-cancer drugs? Acta Pharmacol. Sin. 2009, 30, 501-512. [CrossRef]

63. Zhang, Y.; Talalay, P. Anticarcinogenic activities of organic isothiocyanates: Chemistry and mechanisms. Cancer Res. 1994, 54 (Suppl. 7), 1976s-1981s. [PubMed]

64. Mitsiogianni, M.; Amery, T.; Franco, R.; Zoumpourlis, V.; Pappa, A.; Panayiotidis, M.I. From chemo-prevention to epigenetic regulation: The role of isothiocyanates in skin cancer prevention. Pharmacol. Ther. 2018, 190, 187-201. [CrossRef] [PubMed]

65. Andréasson, E.; Jørgensen, L.B. Chapter four Localization of plant myrosinases and glucosinolates. Recent Adv. Phytochem. 2003, 37, 79-99.

66. Angelino, D.; Jeffery, E. Glucosinolate hydrolysis and bioavailability of resulting isothiocyanates: Focus on glucoraphanin. J. Funct. Foods 2014, 7, 67-76. [CrossRef]

67. Andréasson, E.; Jørgensen, L.B.; Höglund, A.-S.; Rask, L.; Meijer, J. Different myrosinase and idioblast distribution in Arabidopsis and Brassica napus. Plant Physiol. 2001, 127, 1750-1763. [CrossRef] [PubMed] 
68. Del Carmen Martinez-Ballesta, M.; Carvajal, M. Myrosinase in Brassicaceae: The most important issue for glucosinolate turnover and food quality. Phytochem. Rev. 2015, 14, 1045-1051. [CrossRef]

69. Koroleva, O.A.; Davies, A.; Deeken, R.; Thorpe, M.R.; Tomos, A.D.; Hedrich, R. Identification of a new glucosinolate-rich cell type in Arabidopsis flower stalk. Plant Physiol. 2000, 124, 599-608. [CrossRef] [PubMed]

70. Barba, F.J.; Nikmaram, N.; Roohinejad, S.; Khelfa, A.; Zhu, Z.; Koubaa, M. Bioavailability of glucosinolates and their breakdown products: Impact of processing. Front. Nutr. 2016, 3, 24. [CrossRef]

71. Bones, A.M.; Rossiter, J.T. The enzymic and chemically induced decomposition of glucosinolates. Phytochemistry 2006, 67, 1053-1067. [CrossRef]

72. Mithen, R.F.; Dekker, M.; Verkerk, R.; Rabot, S.; Johnson, I.T. The nutritional significance, biosynthesis and bioavailability of glucosinolates in human foods. J. Sci. Food Agric. 2000, 80, 967-984. [CrossRef]

73. Thornalley, P. Cruciferous Vegetables, Isothiocyanates and Indoles (IARC Handbooks of Cancer Prevention); IARC Press: Lyon, France, 2004; pp. 1-261.

74. Halkier, B.A.; Du, L. The biosynthesis of glucosinolates. Trends Plant Sci. 1997, 2, 425-431. [CrossRef]

75. Kissen, R.; Rossiter, J.T.; Bones, A.M. The 'mustard oil bomb': Not so easy to assemble?! Localization, expression and distribution of the components of the myrosinase enzyme system. Phytochem. Rev. 2009, 8, 69-86. [CrossRef]

76. Hanschen, F.S.; Platz, S.; Mewis, I.; Schreiner, M.; Rohn, S.; Kroh, L.W. Thermally induced degradation of sulfur-containing aliphatic glucosinolates in broccoli sprouts (Brassica oleracea var. italica) and model systems. J. Agric. Food Chem. 2012, 60, 2231-2241. [CrossRef] [PubMed]

77. Song, L.; Thornalley, P.J. Effect of storage, processing and cooking on glucosinolate content of Brassica vegetables. Food Chem. Toxicol. 2007, 45, 216-224. [CrossRef] [PubMed]

78. Ciska, E.; Martyniak-Przybyszewska, B.; Kozlowska, H. Content of glucosinolates in cruciferous vegetables grown at the same site for two years under different climatic conditions. J. Agric. Food Chem. 2000, 48, 2862-2867. [CrossRef]

79. Deng, Q.; Zinoviadou, K.G.; Galanakis, C.M.; Orlien, V.; Grimi, N.; Vorobiev, E.; Lebovka, N.; Barba, F.J. The effects of conventional and non-conventional processing on glucosinolates and its derived forms, isothiocyanates: Extraction, degradation, and applications. Food Eng. Rev. 2015, 7, 357-381. [CrossRef]

80. Angelino, D.; Dosz, E.B.; Sun, J.; Hoeflinger, J.L.; Van Tassell, M.L.; Chen, P.; Harnly, J.M.; Miller, M.J.; Jeffery, E.H. Myrosinase-dependent and-independent formation and control of isothiocyanate products of glucosinolate hydrolysis. Front. Plant Sci. 2015, 6, 831. [CrossRef] [PubMed]

81. Egner, P.A.; Kensler, T.W.; Chen, J.-G.; Gange, S.J.; Groopman, J.D.; Friesen, M.D. Quantification of sulforaphane mercapturic acid pathway conjugates in human urine by high-performance liquid chromatography and isotope-dilution tandem mass spectrometry. Chem. Res. Toxicol. 2008, 21, 1991-1996. [CrossRef]

82. Keum, Y.-S.; Jeong, W.-S.; Kong, A.T. Chemoprevention by isothiocyanates and their underlying molecular signaling mechanisms. Mutat. Res. 2004, 555, 191-202. [CrossRef]

83. Talalay, P.; Fahey, J.W. Phytochemicals from cruciferous plants protect against cancer by modulating carcinogen metabolism. J. Nutr. 2001, 131, 3027S-3033S. [CrossRef] [PubMed]

84. Yoxall, V.; Kentish, P.; Coldham, N.; Kuhnert, N.; Sauer, M.J.; Ioannides, C. Modulation of hepatic cytochromes P450 and phase II enzymes by dietary doses of sulforaphane in rats: Implications for its chemopreventive activity. Int. J. Cancer 2005, 117, 356-362. [CrossRef] [PubMed]

85. Telang, U.; Morris, M.E. Effect of orally administered phenethyl isothiocyanate on hepatic gene expression in rats. Mol. Nutr. Food Res. 2010, 54, 1802-1806. [CrossRef] [PubMed]

86. Von Weymarn, L.B.; Chun, J.A.; Hollenberg, P.F. Effects of benzyl and phenethyl isothiocyanate on P450s 2 A6 and 2A13: Potential for chemoprevention in smokers. Carcinogenesis 2006, 27, 782-790. [CrossRef] [PubMed]

87. Gao, S.S.; Chen, X.Y.; Zhu, R.Z.; Choi, B.M.; Kim, B.R. Sulforaphane induces glutathione S-transferase isozymes which detoxify aflatoxin B1-8, 9-epoxide in AML 12 cells. BioFactors 2010, 36, 289-296. [CrossRef]

88. Munday, C.M. Selective induction of phase II enzymes in the urinary bladder of rats by allyl isothiocyanate, a compound derived from Brassica vegetables. Nutr. Cancer 2002, 44, 52-59. [CrossRef] [PubMed]

89. Tan, X.-L.; Shi, M.; Tang, H.; Han, W.; Spivack, S.D. Candidate dietary phytochemicals modulate expression of phase II enzymes GSTP1 and NQO1 in human lung cells. J. Nutr. 2010, 140, 1404-1410. [CrossRef] 
90. Wang, W.; Wang, S.; Howie, A.F.; Beckett, G.J.; Mithen, R.; Bao, Y. Sulforaphane, erucin, and iberin up-regulate thioredoxin reductase 1 expression in human MCF-7 cells. J. Agric. Food Chem. 2005, 53, 1417-1421. [CrossRef]

91. Basten, G.P.; Bao, Y.; Williamson, G. Sulforaphane and its glutathione conjugate but not sulforaphane nitrile induce UDP-glucuronosyl transferase (UGT1A1) and glutathione transferase (GSTA1) in cultured cells. Carcinogenesis 2002, 23, 1399-1404. [CrossRef]

92. Diaz-Moralli, S.; Tarrado-Castellarnau, M.; Miranda, A.; Cascante, M. Targeting cell cycle regulation in cancer therapy. Pharmacol. Ther. 2013, 138, 255-271. [CrossRef] [PubMed]

93. Parnaud, G.; Li, P.; Cassar, G.; Rouimi, P.; Tulliez, J.; Combaret, L.; Gamet-Payrastre, L. Mechanism of sulforaphane-induced cell cycle arrest and apoptosis in human colon cancer cells. Nutr. Cancer 2004, 48, 198-206. [CrossRef] [PubMed]

94. Cheng, Y.-M.; Tsai, C.-C.; Hsu, Y.-C. Sulforaphane, a dietary isothiocyanate, induces G2/M arrest in Cervical cancer cells through CyclinB1 downregulation and GADD45ß/CDC2 association. Int. J. Mol. Sci. 2016, 17, 1530. [CrossRef]

95. Shan, Y.; Sun, C.; Zhao, X.; Wu, K.; Cassidy, A.; Bao, Y. Effect of sulforaphane on cell growth, G0/G1 phase cell progression and apoptosis in human bladder cancer T24 cells. Int. J. Oncol. 2006, 29, 883-888. [CrossRef] [PubMed]

96. Chen, P.-Y.; Lin, K.-C.; Lin, J.-P.; Tang, N.-Y.; Yang, J.-S.; Lu, K.-W.; Chung, J.-G. Phenethyl Isothiocyanate (PEITC) inhibits the growth of human oral squamous carcinoma HSC-3 cells through G0/G1 phase arrest and mitochondria-mediated apoptotic cell death. Evid. Based Complement. Alternat. Med. 2012, 2012, 718320. [CrossRef] [PubMed]

97. Xiao, D.; Srivastava, S.K.; Lew, K.L.; Zeng, Y.; Hershberger, P.; Johnson, C.S.; Trump, D.L.; Singh, S.V. Allyl isothiocyanate, a constituent of cruciferous vegetables, inhibits proliferation of human prostate cancer cells by causing G2/M arrest and inducing apoptosis. Carcinogenesis 2003, 24, 891-897. [CrossRef] [PubMed]

98. Zhang, R.; Loganathan, S.; Humphreys, I.; Srivastava, S.K. Benzyl isothiocyanate-induced DNA damage causes G2/M cell cycle arrest and apoptosis in human pancreatic cancer cells. J. Nutr. 2006, 136, 2728-2734. [CrossRef] [PubMed]

99. Miyoshi, N.; Uchida, K.; Osawa, T.; Nakamura, Y. Benzyl isothiocyanate modifies expression of the G2/M arrest-related genes. BioFactors 2004, 21, 23-26. [CrossRef]

100. Cheung, K.L.; Khor, T.O.; Yu, S.; Kong, A.-N.T. PEITC induces G1 cell cycle arrest on HT-29 cells through the activation of p38 MAPK signaling pathway. AAPS J. 2008, 10, 277. [CrossRef]

101. Jun-Hee, K.; Ki, H.K.; Jung, J.-Y.; Han, H.-S.; Shim, J.H.; Oh, S.; Choi, K.-H.; Choi, E.-S.; Shin, J.-A.; Leem, D.-H. Sulforaphane increases cyclin-dependent kinase inhibitor, p21 protein in human oral carcinoma cells and nude mouse animal model to induce G2/M cell cycle arrest. J. Clin. Biochem. Nutr. 2009, 46, 60-67. [CrossRef]

102. Herman-Antosiewicz, A.; Xiao, H.; Lew, K.L.; Singh, S.V. Induction of p21 protein protects against sulforaphane-induced mitotic arrest in LNCaP human prostate cancer cell line. Mol. Cancer Ther. 2007, 6, 1673-1681. [CrossRef] [PubMed]

103. Matsui, T.-A.; Murata, H.; Sakabe, T.; Sowa, Y.; Horie, N.; Nakanishi, R.; Sakai, T.; Kubo, T. Sulforaphane induces cell cycle arrest and apoptosis in murine osteosarcoma cells in vitro and inhibits tumor growth in vivo. Oncol. Rep. 2007, 18, 1263-1268. [CrossRef]

104. Fimognari, C.; Nüsse, M.; Berti, F.; Iori, R.; Cantelli-Forti, G.; Hrelia, P. A mixture of isothiocyanates induces cyclin B1-and p53-mediated cell-cycle arrest and apoptosis of human T lymphoblastoid cells. Mutat. Res. 2004, 554, 205-214. [CrossRef]

105. Fernald, K.; Kurokawa, M. Evading apoptosis in cancer. Trends Cell Biol. 2013, 23, 620-633. [CrossRef]

106. Zörnig, M.; Hueber, A.-O.; Baum, W.; Evan, G. Apoptosis regulators and their role in tumorigenesis. Biochim. Biophys. Acta 2001, 1551, F1-F37. [CrossRef]

107. Mi, L.; Di Pasqua, A.J.; Chung, F.L. Proteins as binding targets of isothiocyanates in cancer prevention. Carcinogenesis 2011, 32, 1405-1413. [CrossRef]

108. Rudolf, E.; Andělová, H.; Červinka, M. Activation of several concurrent proapoptic pathways by sulforaphane in human colon cancer cells SW620. Food Chem. Toxicol. 2009, 47, 2366-2373. [CrossRef] [PubMed]

109. Yu, R.; Mandlekar, S.; Harvey, K.J.; Ucker, D.S.; Kong, A.N. Chemopreventive isothiocyanates induce apoptosis and caspase-3-like protease activity. Cancer Res. 1998, 58, 402-408. [PubMed] 
110. Mondal, A.; Biswas, R.; Rhee, Y.-H.; Kim, J.; Ahn, J.-C. Sulforaphene promotes Bax/Bcl2, MAPK-dependent human gastric cancer AGS cells apoptosis and inhibits migration via EGFR, p-ERK1/2 downregulation. Gen. Physiol. Biophys. 2016, 35, 25-34. [PubMed]

111. Tsai, S.-C.; Huang, W.-W.; Huang, W.-C.; Lu, C.-C.; Chiang, J.-H.; Peng, S.-F.; Chung, J.-G.; Lin, Y.-H.; Hsu, Y.-M.; Amagaya, S. ERK-modulated intrinsic signaling and G2/M phase arrest contribute to the induction of apoptotic death by allyl isothiocyanate in MDA-MB-468 human breast adenocarcinoma cells. Int. J. Oncol. 2012, 41, 2065-2072. [CrossRef]

112. De Oliveira, J.M.P.F.; Costa, M.; Pedrosa, T.; Pinto, P.; Remédios, C.; Oliveira, H.; Pimentel, F.; Almeida, L.; Santos, C. Sulforaphane induces oxidative stress and death by p53-independent mechanism: Implication of impaired glutathione recycling. PLoS ONE 2014, 9, e92980. [CrossRef]

113. Sarkar, R.; Mukherjee, S.; Biswas, J.; Roy, M. Sulphoraphane, a naturally occurring isothiocyanate induces apoptosis in breast cancer cells by targeting heat shock proteins. Biochem. Biophys. Res. Commun. 2012, 427, 80-85. [CrossRef]

114. Sehrawat, A.; Croix, C.S.; Baty, C.J.; Watkins, S.; Tailor, D.; Singh, R.P.; Singh, S.V. Inhibition of mitochondrial fusion is an early and critical event in breast cancer cell apoptosis by dietary chemopreventative benzyl isothiocyanate. Mitochondrion 2016, 30, 67-77. [CrossRef]

115. Xu, C.; Shen, G.; Yuan, X.; Kim, J.-H.; Gopalkrishnan, A.; Keum, Y.-S.; Nair, S.; Kong, A.-N.T. ERK and JNK signaling pathways are involved in the regulation of activator protein 1 and cell death elicited by three isothiocyanates in human prostate cancer PC-3 cells. Carcinogenesis 2006, 27, 437-445. [CrossRef]

116. Lin, F.; Lin, P.; Zhao, D.; Chen, Y.; Xiao, L.; Qin, W.; Li, D.; Chen, H.; Zhao, B.; Zou, H. Sox2 targets cyclinE, p27 and survivin to regulate androgen-independent human prostate cancer cell proliferation and apoptosis. Cell Prolif. 2012, 45, 207-216. [CrossRef] [PubMed]

117. Gao, N.; Budhraja, A.; Cheng, S.; Liu, E.; Chen, J.; Yang, Z.; Chen, D.; Zhang, Z.; Shi, X. Phenethyl isothiocyanate exhibits antileukemic activity in vitro and in vivo by inactivation of Akt and activation of JNK pathways. Cell Death Dis. 2011, 2, e140. [CrossRef] [PubMed]

118. Cho, S.-D.; Li, G.; Hu, H.; Jiang, C.; Kang, K.-S.; Lee, Y.-S.; Kim, S.-H.; Lu, J. Involvement of c-Jun N-terminal kinase in G2/M arrest and caspase-mediated apoptosis induced by sulforaphane in DU145 prostate cancer cells. Nutr. Cancer 2005, 52, 213-224. [CrossRef]

119. Xiao, D.; Singh, S.V. Phenethyl isothiocyanate-induced apoptosis in p53-deficient PC-3 human prostate cancer cell line is mediated by extracellular signal-regulated kinases. Cancer Res. 2002, 62, 3615-3619.

120. Stan, S.D.; Singh, S.V.; Whitcomb, D.C.; Brand, R.E. Phenethyl isothiocyanate inhibits proliferation and induces apoptosis in pancreatic cancer cells in vitro and in a MIAPaca2 xenograft animal model. Nutr. Cancer 2014, 66, 747-755. [CrossRef] [PubMed]

121. Fimognari, C.; Nüsse, M.; Cesari, R.; Iori, R.; Cantelli-Forti, G.; Hrelia, P. Growth inhibition, cell-cycle arrest and apoptosis in human T-cell leukemia by the isothiocyanate sulforaphane. Carcinogenesis 2002, 23, 581-586. [CrossRef] [PubMed]

122. Jiang, Z.; Liu, X.; Chang, K.; Liu, X.; Xiong, J. Allyl Isothiocyanate Inhibits the Proliferation of Renal Carcinoma Cell Line GRC-1 by Inducing an Imbalance Between Bcl2 and Bax. Med. Sci. Monit. 2016, 22, 4283. [CrossRef]

123. Lee, Y.-J.; Lee, S.-H. Sulforaphane induces antioxidative and antiproliferative responses by generating reactive oxygen species in human bronchial epithelial BEAS-2B cells. J. Korean Med. Sci. 2011, 26, 1474-1482. [CrossRef]

124. Yeh, Y.-T.; Hsu, Y.-N.; Huang, S.-Y.; Lin, J.-S.; Chen, Z.-F.; Chow, N.-H.; Su, S.-H.; Shyu, H.-W.; Lin, C.-C.; Huang, W.-T.; et al. Benzyl isothiocyanate promotes apoptosis of oral cancer cells via an acute redox stress-mediated DNA damage response. Food Chem. Toxicol. 2016, 97, 336-345. [CrossRef]

125. Yeh, Y.T.; Yeh, H.; Su, S.H.; Lin, J.S.; Lee, K.J.; Shyu, H.W.; Chen, Z.F.; Huang, S.Y.; Su, S.J. Phenethyl isothiocyanate induces DNA damage-associated G2/M arrest and subsequent apoptosis in oral cancer cells with varying p53 mutations. Free Radic. Biol. Med. 2014, 74, 1-13. [CrossRef]

126. Safe, S.; Kasiappan, R. Natural products as mechanism-based anticancer agents: Sp transcription factors as targets. Phytother. Res. 2016, 30, 1723-1732. [CrossRef] [PubMed]

127. Beishline, K.; Azizkhan-Clifford, J. Sp1 and the 'hallmarks of cancer'. FEBS J. 2015, 282, 224-258. [CrossRef]

128. Vizcaíno, C.; Mansilla, S.; Portugal, J. Sp1 transcription factor: A long-standing target in cancer chemotherapy. Pharmacol. Ther. 2015, 152, 111-124. [CrossRef] [PubMed] 
129. Hedrick, E.; Cheng, Y.; Jin, U.H.; Kim, K.; Safe, S. Specificity protein (Sp) transcription factors Sp1, Sp3 and Sp4 are non-oncogene addiction genes in cancer cells. Oncotarget 2016, 7, 22245-22256. [CrossRef] [PubMed]

130. Jutooru, I.; Guthrie, A.S.; Chadalapaka, G.; Pathi, S.; Kim, K.; Burghardt, R.; Jin, U.-H.; Safe, S. Mechanism of action of phenethylisothiocyanate and other reactive oxygen species-inducing anticancer agents. Mol. Cell. Biol. 2014, 34, 2382-2395. [CrossRef]

131. Kasiappan, R.; Jutooru, I.; Karki, K.; Hedrick, E.; Safe, S. Benzyl Isothiocyanate (BITC) Induces Reactive Oxygen Species-dependent Repression of STAT3 Protein by Downregulation of Specificity Proteins in Pancreatic Cancer. J. Biol. Chem. 2016, 291, 27122-27133. [CrossRef] [PubMed]

132. Chadalapaka, G.; Jutooru, I.; Safe, S. Celastrol decreases specificity proteins (Sp) and fibroblast growth factor receptor-3 (FGFR3) in bladder cancer cells. Carcinogenesis 2012, 33, 886-894. [CrossRef] [PubMed]

133. Hedrick, E.; Crose, L.; Linardic, C.M.; Safe, S. Histone Deacetylase Inhibitors Inhibit Rhabdomyosarcoma by Reactive Oxygen Species-Dependent Targeting of Specificity Protein Transcription Factors. Mol. Cancer Ther. 2015, 14, 2143-2153. [CrossRef]

134. Hedrick, E.; Li, X.; Safe, S. Penfluridol represses integrin expression in breast cancer through induction of reactive oxygen species and downregulation of Sp transcription factors. Mol. Cancer Ther. 2017, 16, 205-216. [CrossRef]

135. Karki, K.; Hedrick, E.; Kasiappan, R.; Jin, U.-H.; Safe, S. Piperlongumine induces reactive oxygen species (ROS)-dependent downregulation of specificity protein transcription factors. Cancer Prev. Res. (Phila) 2017, 10, 467-477. [CrossRef]

136. Gandhy, S.U.; Kim, K.; Larsen, L.; Rosengren, R.J.; Safe, S. Curcumin and synthetic analogs induce reactive oxygen species and decreases specificity protein (Sp) transcription factors by targeting microRNAs. BMC Cancer 2012, 12, 564. [CrossRef] [PubMed]

137. Noratto, G.D.; Jutooru, I.; Safe, S.; Angel-Morales, G.; Mertens-Talcott, S.U. The drug resistance suppression induced by curcuminoids in colon cancer SW-480 cells is mediated by reactive oxygen species-induced disruption of the microRNA-27a-ZBTB10-Sp axis. Mol. Nutr. Food Res. 2013, 57, 1638-1648. [CrossRef] [PubMed]

138. Takeuchi, H.; Taoka, R.; Mmeje, C.O.; Jinesh, G.G.; Safe, S.; Kamat, A.M. CDODA-Me decreases specificity protein transcription factors and induces apoptosis in bladder cancer cells through induction of reactive oxygen species. Urol Oncol. 2016, 34, e11-e337. [CrossRef] [PubMed]

139. Taoka, R.; Jinesh, G.G.; Xue, W.; Safe, S.; Kamat, A.M. CF3DODA-Me induces apoptosis, degrades Sp1, and blocks the transformation phase of the blebbishield emergency program. Apoptosis 2017, 22, 719-729. [CrossRef] [PubMed]

140. Pathi, S.S.; Jutooru, I.; Chadalapaka, G.; Sreevalsan, S.; Anand, S.; Thatcher, G.R.; Safe, S. GT-094, a NO-NSAID, inhibits colon cancer cell growth by activation of a reactive oxygen species-microRNA-27a: ZBTB10-specificity protein pathway. Mol. Cancer Res. 2011, 9, 195-202. [CrossRef]

141. Safe, S.; Abbruzzese, J.; Abdelrahim, M.; Hedrick, E. Specificity Protein Transcription Factors and Cancer: Opportunities for Drug Development. Cancer Prev. Res. (Phila) 2018, 11, 371-382. [CrossRef] [PubMed]

142. Levine, B. Autophagy and cancer. Nature 2007, 446, 745. [CrossRef] [PubMed]

143. Parzych, K.R.; Klionsky, D.J. An overview of autophagy: Morphology, mechanism, and regulation. Antioxid. Redox Signal. 2014, 20, 460-473. [CrossRef] [PubMed]

144. White, E. Deconvoluting the context-dependent role for autophagy in cancer. Nat. Rev. Cancer 2012, $12,401$. [CrossRef] [PubMed]

145. Amaravadi, R.; Kimmelman, A.C.; White, E. Recent insights into the function of autophagy in cancer. Genes Dev. 2016, 30, 1913-1930. [CrossRef]

146. Yang, Z.J.; Chee, C.E.; Huang, S.; Sinicrope, F.A. The role of autophagy in cancer: Therapeutic implications. Mol. Cancer Ther. 2011, 10, 1533-1541. [CrossRef] [PubMed]

147. Pietrocola, F.; Pol, J.; Vacchelli, E.; Baracco, E.E.; Levesque, S.; Castoldi, F.; Maiuri, M.C.; Madeo, F.; Kroemer, G. Autophagy induction for the treatment of cancer. Autophagy 2016, 12, 1962-1964. [CrossRef] [PubMed]

148. Herman-Antosiewicz, A.; Johnson, D.E.; Singh, S.V. Sulforaphane causes autophagy to inhibit release of cytochrome $C$ and apoptosis in human prostate cancer cells. Cancer Res. 2006, 66, 5828-5835. [CrossRef]

149. Zhang, Q.-C.; Pan, Z.-H.; Liu, B.-N.; Meng, Z.-W.; Wu, X.; Zhou, Q.-H.; Xu, K. Benzyl isothiocyanate induces protective autophagy in human lung cancer cells through an endoplasmic reticulum stress-mediated mechanism. Acta Pharmacol. Sin. 2017, 38, 539. [CrossRef] [PubMed] 
150. Lin, J.-F.; Liao, P.-C.; Lin, Y.-H.; Chen, H.-E.; Lin, Y.-C.; Chou, K.-Y.; Tsai, T.-F.; Hwang, T.I.-S. Benzyl isothiocyanate induces protective autophagy in human prostate cancer cells via inhibition of mTOR signaling. Carcinogenesis 2012, 34, 406-414. [CrossRef] [PubMed]

151. Lin, J.-F.; Tsai, T.-F.; Yang, S.-C.; Lin, Y.-C.; Chen, H.-E.; Chou, K.-Y.; Hwang, T.I.S. Benzyl isothiocyanate induces reactive oxygen species-initiated autophagy and apoptosis in human prostate cancer cells. Oncotarget 2017, 8, 20220-20234. [CrossRef]

152. Wang, H.; Wang, L.; Cao, L.; Zhang, Q.; Song, Q.; Meng, Z.; Wu, X.; Xu, K. Inhibition of autophagy potentiates the anti-metastasis effect of phenethyl isothiocyanate through JAK2/STAT3 pathway in lung cancer cells. Mol. Carcinog. 2018, 57, 522-535. [CrossRef] [PubMed]

153. Chen, H.-E.; Lin, J.-F.; Tsai, T.-F.; Lin, Y.-C.; Chou, K.-Y.; Hwang, T.I.-S. Allyl Isothiocyanate Induces Autophagy through the Up-Regulation of Beclin-1 in Human Prostate Cancer Cells. Am. J. Chin. Med. 2018, 46, 1625-1643. [CrossRef] [PubMed]

154. Pawlik, A.; Wała, M.; Hać, A.; Felczykowska, A.; Herman-Antosiewicz, A. Sulforaphene, an isothiocyanate present in radish plants, inhibits proliferation of human breast cancer cells. Phytomedicine 2017, 29, 1-10. [CrossRef] [PubMed]

155. Lee, Y.J.; Lee, S.H. Pro-oxidant activity of sulforaphane and cisplatin potentiates apoptosis and simultaneously promotes autophagy in malignant mesothelioma cells. Mol. Med. Rep. 2017, 16, 2133-2141. [CrossRef] [PubMed]

156. Hee Kim, Y.; Kim, K.Y.; Jun do, Y.; Kim, J.S.; Kim, Y.H. Inhibition of autophagy enhances dynamin inhibitor-induced apoptosis via promoting Bak activation and mitochondrial damage in human Jurkat $\mathrm{T}$ cells. Biochem. Biophys. Res. Commun. 2016, 478, 1609-1616. [CrossRef]

157. Horwacik, I.; Gaik, M.; Durbas, M.; Boratyn, E.; Zajac, G.; Szychowska, K.; Szczodrak, M.; Koloczek, H.; Rokita, H. Inhibition of autophagy by 3-methyladenine potentiates sulforaphane-induced cell death of BE(2)-C human neuroblastoma cells. Mol. Med. Rep. 2015, 12, 535-542. [CrossRef]

158. Xiao, D.; Bommareddy, A.; Kim, S.H.; Sehrawat, A.; Hahm, E.R.; Singh, S.V. Benzyl isothiocyanate causes FoxO1-mediated autophagic death in human breast cancer cells. PLoS ONE 2012, 7, e32597. [CrossRef]

159. Bommareddy, A.; Hahm, E.-R.; Xiao, D.; Powolny, A.A.; Fisher, A.L.; Jiang, Y.; Singh, S.V. Atg5 Regulates Phenethyl Isothiocyanate-Induced Autophagic and Apoptotic Cell Death in Human Prostate Cancer Cells. Cancer Res. 2009, 69, 3704-3712. [CrossRef]

160. Liu, H.J.; Wang, L.; Kang, L.; Du, J.; Li, S.; Cui, H.X. Sulforaphane-N-Acetyl-Cysteine Induces Autophagy Through Activation of ERK1/2 in U87MG and U373MG Cells. Cell. Physiol. Biochem. 2018, 51, 528-542. [CrossRef]

161. Yang, F.; Wang, F.; Liu, Y.; Wang, S.; Li, X.; Huang, Y.; Xia, Y.; Cao, C. Sulforaphane induces autophagy by inhibition of HDAC6-mediated PTEN activation in triple negative breast cancer cells. Life Sci. 2018, 213, 149-157. [CrossRef]

162. Milczarek, M.; Wiktorska, K.; Mielczarek, L.; Koronkiewicz, M.; Dąbrowska, A.; Lubelska, K.; Matosiuk, D.; Chilmonczyk, Z. Autophagic cell death and premature senescence: New mechanism of 5-fluorouracil and sulforaphane synergistic anticancer effect in MDA-MB-231 triple negative breast cancer cell line. Food Chem. Toxicol. 2018, 111, 1-8. [CrossRef] [PubMed]

163. Reik, W.; Walter, J. Genomic imprinting: Parental influence on the genome. Nat. Rev. Genet. 2001, 2, $21-32$. [CrossRef]

164. Ferguson-Smith, A.C.; Surani, M.A. Imprinting and the epigenetic asymmetry between parental genomes. Science 2001, 293, 1086-1089. [CrossRef] [PubMed]

165. Li, E.; Beard, C.; Jaenisch, R. Role for DNA methylation in genomic imprinting. Nature 1993, 366, 362-365. [CrossRef]

166. Avner, P.; Heard, E. X-chromosome inactivation: Counting, choice and initiation. Nat. Rev. Genet. 2001, 2, 59-67. [CrossRef]

167. Panning, B.; Jaenisch, R. RNA and the epigenetic regulation of $X$ chromosome inactivation. Cell 1998, 93, 305-308. [CrossRef]

168. Maltepe, E.; Bakardjiev, A.I.; Fisher, S.J. The placenta: Transcriptional, epigenetic, and physiological integration during development. J. Clin. Investig. 2010, 120, 1016-1025. [CrossRef]

169. Hemberger, M. Epigenetic landscape required for placental development. Cell. Mol. Life Sci. 2007, 64, 2422-2436. [CrossRef] [PubMed] 
170. Santos, F.; Hendrich, B.; Reik, W.; Dean, W. Dynamic reprogramming of DNA methylation in the early mouse embryo. Dev. Biol. 2002, 241, 172-182. [CrossRef]

171. Toyota, M.; Suzuki, H.; Sasaki, Y.; Maruyama, R.; Imai, K.; Shinomura, Y.; Tokino, T. Epigenetic silencing of microRNA-34b/c and B-cell translocation gene 4 is associated with CpG island methylation in colorectal cancer. Cancer Res. 2008, 68, 4123-4132. [CrossRef]

172. Lehmann, U.; Hasemeier, B.; Christgen, M.; Müller, M.; Römermann, D.; Länger, F.; Kreipe, H. Epigenetic inactivation of microRNA gene hsa-mir-9-1 in human breast cancer. J. Pathol. 2008, 214, 17-24. [CrossRef]

173. Zhang, C.; Li, H.; Zhou, G.; Zhang, Q.; Zhang, T.; Li, J.; Zhang, J.; Hou, J.; Liew, C.; Yin, D. Transcriptional silencing of the TMS1/ASC tumour suppressor gene by an epigenetic mechanism in hepatocellular carcinoma cells. J. Pathol. 2007, 212, 134-142. [CrossRef]

174. Franco, R.; Schoneveld, O.; Georgakilas, A.G.; Panayiotidis, M.I. Oxidative stress, DNA methylation and carcinogenesis. Cancer Lett. 2008, 266, 6-11. [CrossRef] [PubMed]

175. Ziech, D.; Franco, R.; Pappa, A.; Malamou-Mitsi, V.; Georgakila, S.; Georgakilas, A.G.; Panayiotidis, M.I. The role of epigenetics in environmental and occupational carcinogenesis. Chem.-Biol. Interact. 2010, 188, 340-349. [CrossRef] [PubMed]

176. Ziech, D.; Franco, R.; Pappa, A.; Panayiotidis, M.I. Reactive oxygen species (ROS)-induced genetic and epigenetic alterations in human carcinogenesis. Mutat. Res. 2011, 711, 167-173. [CrossRef]

177. Eckschlager, T.; Plch, J.; Stiborova, M.; Hrabeta, J. Histone Deacetylase Inhibitors as Anticancer Drugs. Int. J. Mol. Sci. 2017, 18, 1414. [CrossRef]

178. Ho, E.; Clarke, J.D.; Dashwood, R.H. Dietary sulforaphane, a histone deacetylase inhibitor for cancer prevention. J. Nutr. 2009, 139, 2393-2396. [CrossRef] [PubMed]

179. Yuanfeng, W.; Gongnian, X.; Jianwei, M.; Shiwang, L.; Jun, H.; Lehe, M. Dietary sulforaphane inhibits histone deacetylase activity in B16 melanoma cells. J. Funct. Foods 2015, 18, 182-189. [CrossRef]

180. Rajendran, P.; Kidane, A.I.; Yu, T.-W.; Dashwood, W.-M.; Bisson, W.H.; Löhr, C.V.; Ho, E.; Williams, D.E.; Dashwood, R.H. HDAC turnover, CtIP acetylation and dysregulated DNA damage signaling in colon cancer cells treated with sulforaphane and related dietary isothiocyanates. Epigenetics 2013, 8, 612-623. [CrossRef]

181. Su, Z.-Y.; Zhang, C.; Lee, J.H.; Shu, L.; Wu, T.-Y.; Khor, T.O.; Conney, A.H.; Lu, Y.-P.; Kong, A.-N.T. Requirement and epigenetics reprogramming of Nrf2 in suppression of tumor promoter TPA-induced mouse skin cell transformation by sulforaphane. Cancer Prev. Res. (Phila) 2014, 7, 319-329. [CrossRef] [PubMed]

182. Wang, L.G.; Liu, X.M.; Fang, Y.; Dai, W.; Chiao, F.B.; Puccio, G.M.; Feng, J.; Liu, D.; Chiao, J.W. De-repression of the p21 promoter in prostate cancer cells by an isothiocyanate via inhibition of HDACs and c-Myc. Int. J. Oncol. 2008, 33, 375-380. [CrossRef] [PubMed]

183. Myzak, M.C.; Hardin, K.; Wang, R.; Dashwood, R.H.; Ho, E. Sulforaphane inhibits histone deacetylase activity in BPH-1, LnCaP and PC-3 prostate epithelial cells. Carcinogenesis 2005, 27, 811-819. [CrossRef]

184. Abbaoui, B.; Telu, K.H.; Lucas, C.R.; Thomas-Ahner, J.M.; Schwartz, S.J.; Clinton, S.K.; Freitas, M.A.; Mortazavi, A. The impact of cruciferous vegetable isothiocyanates on histone acetylation and histone phosphorylation in bladder cancer. J. Proteom. 2017, 156, 94-103. [CrossRef]

185. Batra, S.; Sahu, R.P.; Kandala, P.K.; Srivastava, S.K. Benzyl isothiocyanate-mediated inhibition of histone deacetylase leads to NF-kB turnoff in human pancreatic carcinoma cells. Mol. Cancer Ther. 2010, 9, 1596-1608. [CrossRef] [PubMed]

186. Beklemisheva, A.A.; Fang, Y.; Feng, J.; Ma, X.; Dai, W.; Chiao, J.W. Epigenetic mechanism of growth inhibition induced by phenylhexyl isothiocyanate in prostate cancer cells. Anticancer Res. 2006, 26, 1225-1230.

187. Jiang, L.-L.; Zhou, S.-J.; Zhang, X.-M.; Chen, H.-Q.; Liu, W. Sulforaphane suppresses in vitro and in vivo lung tumorigenesis through downregulation of HDAC activity. Biomed. Pharmacother. 2016, 78, 74-80. [CrossRef] [PubMed]

188. Myzak, M.C.; Karplus, P.A.; Chung, F.-L.; Dashwood, R.H. A novel mechanism of chemoprotection by sulforaphane. Cancer Res. 2004, 64, 5767-5774. [CrossRef]

189. Dashwood, R.H.; Myzak, M.C.; Ho, E. Dietary HDAC inhibitors: Time to rethink weak ligands in cancer chemoprevention? Carcinogenesis 2005, 27, 344-349. [CrossRef]

190. Dashwood, R.H.; Ho, E. Dietary agents as histone deacetylase inhibitors: Sulforaphane and structurally related isothiocyanates. Nutr. Rev. 2008, 66 (Suppl. 1), S36-S38. [CrossRef]

191. Tsai, H.-C.; Baylin, S.B. Cancer epigenetics: Linking basic biology to clinical medicine. Cell Res. 2011, 21, 502-517. [CrossRef] 
192. Kulis, M.; Esteller, M. DNA methylation and cancer. Adv. Genet. 2010, 70, 27-56. [PubMed]

193. Jones, P.A.; Liang, G. Rethinking how DNA methylation patterns are maintained. Nat. Rev. Genet. 2009, 10, 805-811. [CrossRef] [PubMed]

194. Okano, M.; Bell, D.W.; Haber, D.A.; Li, E. DNA methyltransferases Dnmt3a and Dnmt3b are essential for de novo methylation and mammalian development. Cell 1999, 99, 247-257. [CrossRef]

195. Akhavan-Niaki, H.; Samadani, A.A. DNA methylation and cancer development: Molecular mechanism. Cell Biochem. Biophys. 2013, 67, 501-513. [CrossRef]

196. Kaufman-Szymczyk, A.; Majewski, G.; Lubecka-Pietruszewska, K.; Fabianowska-Majewska, K. The Role of Sulforaphane in Epigenetic Mechanisms, Including Interdependence between Histone Modification and DNA Methylation. Int. J. Mol. Sci. 2015, 16, 29732-29743. [CrossRef] [PubMed]

197. Wong, C.P.; Hsu, A.; Buchanan, A.; Palomera-Sanchez, Z.; Beaver, L.M.; Houseman, E.A.; Williams, D.E.; Dashwood, R.H.; Ho, E. Effects of sulforaphane and 3,3'-diindolylmethane on genome-wide promoter methylation in normal prostate epithelial cells and prostate cancer cells. PLoS ONE 2014, 9, e86787. [CrossRef]

198. Hsu, A.; Wong, C.P.; Yu, Z.; Williams, D.E.; Dashwood, R.H.; Ho, E. Promoter de-methylation of cyclin D2 by sulforaphane in prostate cancer cells. Clin. Epigenet. 2011, 3, 3. [CrossRef]

199. Jiang, S.; Ma, X.; Huang, Y.; Xu, Y.; Zheng, R.; Chiao, J.-W. Reactivating aberrantly hypermethylated p15 gene in leukemic $\mathrm{T}$ cells by a phenylhexyl isothiocyanate mediated inter-active mechanism on DNA and chromatin. J. Hematol. Oncol. 2010, 3, 48. [CrossRef] [PubMed]

200. Zhang, C.; Su, Z.Y.; Khor, T.O.; Shu, L.; Kong, A.N. Sulforaphane enhances Nrf2 expression in prostate cancer TRAMP C1 cells through epigenetic regulation. Biochem. Pharmacol. 2013, 85, 1398-1404. [CrossRef] [PubMed]

201. Meeran, S.M.; Patel, S.N.; Li, Y.; Shukla, S.; Tollefsbol, T.O. Bioactive dietary supplements reactivate ER expression in ER-negative breast cancer cells by active chromatin modifications. PLoS ONE 2012, 7, e37748. [CrossRef]

202. Meeran, S.M.; Patel, S.N.; Tollefsbol, T.O. Sulforaphane causes epigenetic repression of hTERT expression in human breast cancer cell lines. PLoS ONE 2010, 5, e11457. [CrossRef]

203. Boyanapalli, S.S.; Li, W.; Fuentes, F.; Guo, Y.; Ramirez, C.N.; Gonzalez, X.-P.; Pung, D.; Kong, A.-N.T. Epigenetic reactivation of RASSF1A by phenethyl isothiocyanate (PEITC) and promotion of apoptosis in LNCaP cells. Pharmacol. Res. 2016, 114, 175-184. [CrossRef] [PubMed]

204. Jansson, M.D.; Lund, A.H. MicroRNA and cancer. Mol. Oncol. 2012, 6, 590-610. [CrossRef] [PubMed]

205. Slaby, O.; Sachlova, M.; Brezkova, V.; Hezova, R.; Kovarikova, A.; Bischofová, S.; Sevcikova, S.; Bienertova-Vasku, J.; Vasku, A.; Svoboda, M. Identification of microRNAs regulated by isothiocyanates and association of polymorphisms inside their target sites with risk of sporadic colorectal cancer. Nutr. Cancer 2013, 65, 247-254. [CrossRef] [PubMed]

206. Zhang, C.; Shu, L.; Kim, H.; Khor, T.O.; Wu, R.; Li, W.; Kong, A.N.T. Phenethyl isothiocyanate (PEITC) suppresses prostate cancer cell invasion epigenetically through regulating microRNA-194. Mol. Nutr. Food Res. 2016, 60, 1427-1436. [CrossRef]

207. Wang, D.X.; Zou, Y.J.; Zhuang, X.B.; Chen, S.X.; Lin, Y.; Li, W.L.; Lin, J.J.; Lin, Z.Q. Sulforaphane suppresses EMT and metastasis in human lung cancer through miR-616-5p-mediated GSK3beta/beta-catenin signaling pathways. Acta Pharmacol. Sin. 2017, 38, 241-251. [CrossRef]

208. Lan, F.; Pan, Q.; Yu, H.; Yue, X. Sulforaphane enhances temozolomide-induced apoptosis because of downregulation of miR-21 via Wnt/beta-catenin signaling in glioblastoma. J. Neurochem. 2015, 134, 811-818. [CrossRef] [PubMed]

209. Shan, Y.; Zhang, L.; Bao, Y.; Li, B.; He, C.; Gao, M.; Feng, X.; Xu, W.; Zhang, X.; Wang, S. Epithelial-mesenchymal transition, a novel target of sulforaphane via COX-2/MMP2, 9/Snail, ZEB1 and miR-200c/ZEB1 pathways in human bladder cancer cells. J. Nutr. Biochem. 2013, 24, 1062-1069. [CrossRef]

210. Xiao, J.; Gong, A.Y.; Eischeid, A.N.; Chen, D.; Deng, C.; Young, C.Y.; Chen, X.M. miR-141 modulates androgen receptor transcriptional activity in human prostate cancer cells through targeting the small heterodimer partner protein. Prostate 2012, 72, 1514-1522. [CrossRef]

211. Yu, C.; Gong, A.Y.; Chen, D.; Solelo Leon, D.; Young, C.Y.; Chen, X.M. Phenethyl isothiocyanate inhibits androgen receptor-regulated transcriptional activity in prostate cancer cells through suppressing PCAF. Mol. Nutr. Food Res. 2013, 57, 1825-1833. [CrossRef] [PubMed] 
212. Moserle, L.; Casanovas, O. Anti-angiogenesis and metastasis: A tumour and stromal cell alliance. J. Intern. Med. 2013, 273, 128-137. [CrossRef] [PubMed]

213. Rudek, M.A.; Venitz, J.; Figg, W.D. Matrix metalloproteinase inhibitors: Do they have a place in anticancer therapy? Pharmacother. J. Hum. Pharmacol. Drug Ther. 2002, 22, 705-720. [CrossRef]

214. Wang, Z.; Dabrosin, C.; Yin, X.; Fuster, M.M.; Arreola, A.; Rathmell, W.K.; Generali, D.; Nagaraju, G.P.; El-Rayes, B.; Ribatti, D.; et al. Broad targeting of angiogenesis for cancer prevention and therapy. Semin. Cancer Biol. 2015, 35, S224-S243. [CrossRef] [PubMed]

215. Sato, Y. Molecular mechanism of angiogenesis Transcription factors and their therapeutic relevance. Pharmacol. Ther. 2000, 87, 51-60. [CrossRef]

216. Thejass, P.; Kuttan, G. Inhibition of endothelial cell differentiation and proinflammatory cytokine production during angiogenesis by allyl isothiocyanate and phenyl isothiocyanate. Integr. Cancer Ther. 2007, 6, 389-399. [CrossRef]

217. Lai, K.-C.; Lu, C.-C.; Tang, Y.-J.; Chiang, J.-H.; Kuo, D.-H.; Chen, F.-A.; Chen, I.-L.; Yang, J.-S. Allyl isothiocyanate inhibits cell metastasis through suppression of the MAPK pathways in epidermal growth factor-stimulated HT29 human colorectal adenocarcinoma cells. Oncol. Rep. 2014, 31, 189-196. [CrossRef]

218. Xiao, D.; Singh, S.V. Phenethyl isothiocyanate inhibits angiogenesis in vitro and ex vivo. Cancer Res. 2007, 67, 2239-2246. [CrossRef]

219. Zhu, Y.; Zhang, L.; Zhang, G.-D.; Wang, H.-O.; Liu, M.-Y.; Jiang, Y.; Qi, L.-S.; Li, Q.; Yang, P. Potential mechanisms of benzyl isothiocyanate suppression of invasion and angiogenesis by the U87MG human glioma cell line. Asian Pac. J. Cancer Prev. 2014, 15, 8225-8228. [CrossRef]

220. Yang, Y.; Sun, M.; Wang, L.; Jiao, B. HIFs, angiogenesis, and cancer. J. Cell. Biochem. 2013, 114, 967-974. [CrossRef]

221. Kim, D.H.; Sung, B.; Kang, Y.J.; Hwang, S.Y.; Kim, M.J.; Yoon, J.-H.; Im, E.; Kim, N.D. Sulforaphane inhibits hypoxia-induced HIF- $1 \alpha$ and VEGF expression and migration of human colon cancer cells. Int. J. Oncol. 2015, 47, 2226-2232. [CrossRef]

222. Wang, X.-H.; Cavell, B.E.; Syed Alwi, S.S.; Packham, G. Inhibition of hypoxia inducible factor by phenethyl isothiocyanate. Biochem. Pharmacol. 2009, 78, 261-272. [CrossRef]

223. Gupta, B.; Chiang, L.; Chae, K.; Lee, D.-H. Phenethyl isothiocyanate inhibits hypoxia-induced accumulation of HIF-1 $\alpha$ and VEGF expression in human glioma cells. Food Chem. 2013, 141, 1841-1846. [CrossRef]

224. Chaw, S.; Majeed, A.A.; Dalley, A.; Chan, A.; Stein, S.; Farah, C. Epithelial to mesenchymal transition (EMT) biomarkers-E-cadherin, beta-catenin, APC and Vimentin-in oral squamous cell carcinogenesis and transformation. Oral Oncol. 2012, 48, 997-1006. [CrossRef]

225. Shih, J.-Y.; Yang, P.-C. The EMT regulator slug and lung carcinogenesis. Carcinogenesis 2011, 32, $1299-1304$. [CrossRef]

226. Wang, L.; Tian, Z.; Yang, Q.; Li, H.; Guan, H.; Shi, B.; Hou, P.; Ji, M. Sulforaphane inhibits thyroid cancer cell growth and invasiveness through the reactive oxygen species-dependent pathway. Oncotarget 2015, 6, 25917-25931. [CrossRef]

227. Sehrawat, A.; Kim, S.-H.; Vogt, A.; Singh, S.V. Suppression of FOXQ1 in benzyl isothiocyanate-mediated inhibition of epithelial-mesenchymal transition in human breast cancer cells. Carcinogenesis 2012, 34, 864-873. [CrossRef]

228. Milkiewicz, M.; Roudier, E.; Doyle, J.L.; Trifonova, A.; Birot, O.; Haas, T.L. Identification of a Mechanism Underlying Regulation of the Anti-Angiogenic Forkhead Transcription Factor FoxO1 in Cultured Endothelial Cells and Ischemic Muscle. Am. J. Pathol. 2011, 178, 935-944. [CrossRef] [PubMed]

229. Lai, K.-C.; Huang, A.-C.; Hsu, S.-C.; Kuo, C.-L.; Yang, J.-S.; Wu, S.-H.; Chung, J.-G. Benzyl isothiocyanate (BITC) inhibits migration and invasion of human colon cancer HT29 cells by inhibiting matrix metalloproteinase-2/-9 and urokinase plasminogen (uPA) through PKC and MAPK signaling pathway. J. Agric. Food Chem. 2010, 58, 2935-2942. [CrossRef]

230. Jackson, S.J.T.; Singletary, K.W.; Venema, R.C. Sulforaphane suppresses angiogenesis and disrupts endothelial mitotic progression and microtubule polymerization. Vascul. Pharmacol. 2007, 46, 77-84. [CrossRef]

231. Bertl, E.; Bartsch, H.; Gerhauser, C. Inhibition of angiogenesis and endothelial cell functions are novel sulforaphane-mediated mechanisms in chemoprevention. Mol. Cancer Ther. 2006, 5, 575-585. [CrossRef]

232. Abdull, R.; Ahmad, F.; Noor, N.M. Cruciferous vegetables: Dietary phytochemicals for cancer prevention. Asian Pac. J. Cancer Prev. 2013, 14, 1565-1570. [CrossRef] 
233. Sahu, R.P.; Srivastava, S.K. The role of STAT-3 in the induction of apoptosis in pancreatic cancer cells by benzyl isothiocyanate. J. Natl. Cancer Inst. 2009, 101, 176-193. [CrossRef] [PubMed]

234. Murillo, G.; Mehta, R.G. Cruciferous vegetables and cancer prevention. Nutr. Cancer 2001, 41, 17-28. [CrossRef] [PubMed]

235. Talalay, P.; Zhang, Y. Chemoprotection against Cancer by Isothiocyanates and Glucosinolates; Portland Press Limited: London, UK, 1996.

236. Fahey, J.W.; Zhang, Y.; Talalay, P. Broccoli sprouts: An exceptionally rich source of inducers of enzymes that protect against chemical carcinogens. Proc. Natl. Acad. Sci. USA 1997, 94, 10367-10372. [CrossRef] [PubMed]

237. Zhang, Y.; Talalay, P.; Cho, C.G.; Posner, G.H. A major inducer of anticarcinogenic protective enzymes from broccoli: Isolation and elucidation of structure. Proc. Natl. Acad. Sci. USA 1992, 89, 2399-2403. [CrossRef]

238. Brennan, P.; Hsu, C.C.; Moullan, N.; Szeszenia-Dabrowska, N.; Lissowska, J.; Zaridze, D.; Rudnai, P.; Fabianova, E.; Mates, D.; Bencko, V. Effect of cruciferous vegetables on lung cancer in patients stratified by genetic status: A mendelian randomisation approach. Lancet 2005, 366, 1558-1560. [CrossRef]

239. Zhao, H.; Lin, J.; Grossman, H.B.; Hernandez, L.M.; Dinney, C.P.; Wu, X. Dietary isothiocyanates, GSTM1, GSTT1, NAT2 polymorphisms and bladder cancer risk. Int. J. Cancer 2007, 120, 2208-2213. [CrossRef]

240. Seow, A.; Yuan, J.-M.; Sun, C.-L.; Van Den Berg, D.; Lee, H.-P.; Yu, M.C. Dietary isothiocyanates, glutathione S-transferase polymorphisms and colorectal cancer risk in the Singapore Chinese Health Study. Carcinogenesis 2002, 23, 2055-2061. [CrossRef]

241. Higdon, J.V.; Delage, B.; Williams, D.E.; Dashwood, R.H. Cruciferous vegetables and human cancer risk: Epidemiologic evidence and mechanistic basis. Pharmacol. Res. 2007, 55, 224-236. [CrossRef]

242. Seow, A.; Vainio, H.; Mimi, C.Y. Effect of glutathione-S-transferase polymorphisms on the cancer preventive potential of isothiocyanates: An epidemiological perspective. Mutat. Res. 2005, 592, 58-67. [CrossRef]

243. Zhao, B.; Seow, A.; Lee, E.J.; Poh, W.-T.; Teh, M.; Eng, P.; Wang, Y.-T.; Tan, W.-C.; Mimi, C.Y.; Lee, H.-P. Dietary isothiocyanates, glutathione S-transferase-M1,-T1 polymorphisms and lung cancer risk among Chinese women in Singapore. Cancer Epidemiol. Biomark. Prev. 2001, 10, 1063-1067.

244. Cai, X.; Yang, L.; Chen, H.; Wang, C. An updated meta-analysis of the association between GSTM1 polymorphism and colorectal cancer in Asians. Tumor Biol. 2014, 35, 949-953. [CrossRef]

245. Zhao, Y.; Wang, B.; Hu, K.; Wang, J.; Lu, S.; Zhang, Y.; Lu, W.; Zhao, E.; Yuan, L. Glutathione S-transferase $\theta 1$ polymorphism contributes to lung cancer susceptibility: A meta-analysis of 26 case-control studies. Oncol. Lett. 2015, 9, 1947-1953. [CrossRef]

246. Yang, H.; Yang, S.; Liu, J.; Shao, F.; Wang, H.; Wang, Y. The association of GSTM1 deletion polymorphism with lung cancer risk in Chinese population: Evidence from an updated meta-analysis. Sci. Rep. 2015, 5, 9392. [CrossRef] [PubMed]

247. Vogtmann, E.; Xiang, Y.-B.; Li, H.-L.; Cai, Q.; Wu, Q.-J.; Xie, L.; Li, G.-L.; Yang, G.; Waterbor, J.W.; Levitan, E.B.; et al. Cruciferous vegetables, glutathione S-transferase polymorphisms, and the risk of colorectal cancer among Chinese men. Ann. Epidemiol. 2014, 24, 44-49. [CrossRef] [PubMed]

248. Tan, Z.; Feng, M.; Luo, Y.; Sun, C.; Fan, Z.; Tan, Y.; Fu, B.; Lang, J. GSTP1 Ile105Val polymorphism and colorectal cancer risk: An updated analysis. Gene 2013, 527, 275-282. [CrossRef]

249. Wang, J.; Han, L.; Zhang, W.; Wang, J.; Ni, Q.; Shen, M.; Gao, Y. [A case-control study on the association between urinary levels of isothiocyanates and the risk of pancreatic cancer]. Zhonghua Yu Fang Yi Xue Za Zhi. 2014, 48, 172-176. [PubMed]

250. Yang, G.; Gao, Y.T.; Shu, X.O.; Cai, Q.; Li, G.L.; Li, H.L.; Ji, B.T.; Rothman, N.; Dyba, M.; Xiang, Y.B.; et al. Isothiocyanate exposure, glutathione $\mathrm{S}$-transferase polymorphisms, and colorectal cancer risk. Am. J. Clin. Nutr. 2010, 91, 704-711. [CrossRef] [PubMed]

251. Kolonel, L.N.; Hankin, J.H.; Whittemore, A.S.; Wu, A.H.; Gallagher, R.P.; Wilkens, L.R.; John, E.M.; Howe, G.R.; Dreon, D.M.; West, D.W. Vegetables, fruits, legumes and prostate cancer: A multiethnic case-control study. Cancer Epidemiol. Biomark. Prev. 2000, 9, 795-804.

252. Tang, L.; Zirpoli, G.R.; Jayaprakash, V.; Reid, M.E.; McCann, S.E.; Nwogu, C.E.; Zhang, Y.; Ambrosone, C.B.; Moysich, K.B. Cruciferous vegetable intake is inversely associated with lung cancer risk among smokers: A case-control study. BMC Cancer 2010, 10, 1-9. [CrossRef] [PubMed]

253. Neuhouser, M.L.; Patterson, R.E.; Thornquist, M.D.; Omenn, G.S.; King, I.B.; Goodman, G.E. Fruits and vegetables are associated with lower lung cancer risk only in the placebo arm of the $\beta$-carotene and retinol efficacy trial (CARET). Cancer Epidemiol. Biomark. Prev. 2003, 12, 350-358. 
254. Fowke, J.H.; Chung, F.-L.; Jin, F.; Qi, D.; Cai, Q.; Conaway, C.; Cheng, J.-R.; Shu, X.-O.; Gao, Y.-T.; Zheng, W. Urinary isothiocyanate levels, brassica, and human breast cancer. Cancer Res. 2003, 63, 3980-3986. [PubMed]

255. Ambrosone, C.B.; McCann, S.E.; Freudenheim, J.L.; Marshall, J.R.; Zhang, Y.; Shields, P.G. Breast cancer risk in premenopausal women is inversely associated with consumption of broccoli, a source of isothiocyanates, but is not modified by GST genotype. J. Nutr. 2004, 134, 1134-1138. [CrossRef] [PubMed]

256. Jain, M.G.; Hislop, G.T.; Howe, G.R.; Ghadirian, P. Plant foods, antioxidants, and prostate cancer risk: Findings from case-control studies in Canada. Nutr. Cancer 1999, 34, 173-184. [CrossRef]

257. Cohen, J.H.; Kristal, A.R.; Stanford, J.L. Fruit and vegetable intakes and prostate cancer risk. J. Natl. Cancer Inst. 2000, 92, 61-68. [CrossRef] [PubMed]

258. Romagnolo, D.F.; Selmin, O.I. Flavonoids and cancer prevention: A review of the evidence. J. Nutr. Gerontol. Geriatr. 2012, 31, 206-238. [CrossRef]

259. Wu, Q.J.; Wang, J.; Gao, J.; Zhang, W.; Han, L.H.; Gao, S.; Gao, Y.T.; Ji, B.T.; Zheng, W.; Shu, X.O.; et al. Urinary isothiocyanates level and liver cancer risk: A nested case-control study in Shanghai, China. Nutr. Cancer 2014, 66, 1023-1029. [CrossRef]

260. Fowke, J.H.; Gao, Y.-T.; Chow, W.-H.; Cai, Q.; Shu, X.-O.; Li, H.-1.; Ji, B.-T.; Rothman, N.; Yang, G.; Chung, F.-L.; et al. Urinary isothiocyanate levels and lung cancer risk among non-smoking women: A prospective investigation. Lung Cancer 2011, 73, 18-24. [CrossRef]

261. Wu, C.L.; Huang, A.C.; Yang, J.S.; Liao, C.L.; Lu, H.F.; Chou, S.T.; Ma, C.Y.; Hsia, T.C.; Ko, Y.C.; Chung, J.G. Benzyl isothiocyanate (BITC) and phenethyl isothiocyanate (PEITC)-mediated generation of reactive oxygen species causes cell cycle arrest and induces apoptosis via activation of caspase-3, mitochondria dysfunction and nitric oxide (NO) in human osteogenic sarcoma U-2 OS cells. J. Orth. Res. 2011, 29, 1199-1209.

262. Xiao, D.; Vogel, V.; Singh, S.V. Benzyl isothiocyanate-induced apoptosis in human breast cancer cells is initiated by reactive oxygen species and regulated by Bax and Bak. Mol. Cancer Ther. 2006, 5, 2931-2945. [CrossRef]

263. Tripathi, K.; Hussein, U.K.; Anupalli, R.; Barnett, R.; Bachaboina, L.; Scalici, J.; Rocconi, R.P.; Owen, L.B.; Piazza, G.A.; Palle, K. Allyl isothiocyanate induces replication-associated DNA damage response in NSCLC cells and sensitizes to ionizing radiation. Oncotarget 2015, 6, 5237. [CrossRef] [PubMed]

264. Hwang, E.-S.; Lee, H.J. Effects of phenylethyl isothiocyanate and its metabolite on cell-cycle arrest and apoptosis in LNCaP human prostate cancer cells. Int. J. Food Sci. Nutr. 2010, 61, 324-336. [CrossRef]

265. Pappa, G.; Lichtenberg, M.; Iori, R.; Barillari, J.; Bartsch, H.; Gerhäuser, C. Comparison of growth inhibition profiles and mechanisms of apoptosis induction in human colon cancer cell lines by isothiocyanates and indoles from Brassicaceae. Mutat. Res. 2006, 599, 76-87. [CrossRef]

266. Ma, X.; Fang, Y.; Beklemisheva, A.; Dai, W.; Feng, J.; Ahmed, T.; Liu, D.; Chiao, J. Phenylhexyl isothiocyanate inhibits histone deacetylases and remodels chromatins to induce growth arrest in human leukemia cells. Int. J. Oncol. 2006, 28, 1287-1293. [CrossRef] [PubMed]

267. Rajendran, P.; Delage, B.; Dashwood, W.M.; Yu, T.-W.; Wuth, B.; Williams, D.E.; Ho, E.; Dashwood, R.H. Histone deacetylase turnover and recovery in sulforaphane-treated colon cancer cells: Competing actions of 14-3-3 and Pin1 in HDAC3/SMRT corepressor complex dissociation/reassembly. Mol. Cancer 2011, 10, 68. [CrossRef] [PubMed]

268. Wang, L.G.; Beklemisheva, A.; Liu, X.M.; Ferrari, A.C.; Feng, J.; Chiao, J.W. Dual action on promoter demethylation and chromatin by an isothiocyanate restored GSTP1 silenced in prostate cancer. Mol. Carcinog. 2007, 46, 24-31. [CrossRef] [PubMed]

269. Xu, C.; Shen, G.; Chen, C.; Gélinas, C.; Ah-Ng, T.K. Suppression of NF-[kappa] B and NF-[kappa] B-regulated gene expression by sulforaphane and PEITC through I [kappa] B [alpha], IKK pathway in human prostate cancer PC-3 cells. Oncogene 2005, 24, 4486. [CrossRef] [PubMed]

270. Boreddy, S.R.; Sahu, R.P.; Srivastava, S.K. Benzyl isothiocyanate suppresses pancreatic tumor angiogenesis and invasion by inhibiting HIF- $\alpha$ /VEGF/Rho-GTPases: Pivotal role of STAT-3. PLoS ONE 2011, 6, e25799. [CrossRef] [PubMed]

271. Lawson, A.P.; Long, M.J.C.; Coffey, R.T.; Qian, Y.; Weerapana, E.; El Oualid, F.; Hedstrom, L. Naturally Occurring Isothiocyanates Exert Anticancer Effects by Inhibiting Deubiquitinating Enzymes. Cancer Res. 2015, 75, 5130-5142. [CrossRef] [PubMed] 
272. Mi, L.; Xiao, Z.; Hood, B.L.; Dakshanamurthy, S.; Wang, X.; Govind, S.; Conrads, T.P.; Veenstra, T.D.; Chung, F.-L. Covalent binding to tubulin by isothiocyanates A mechanism of cell growth arrest and apoptosis. J. Biol. Chem. 2008, 283, 22136-22146. [CrossRef] [PubMed]

273. Smith, T.K.; Lund, E.K.; Parker, M.L.; Clarke, R.G.; Johnson, I.T. Allyl-isothiocyanate causes mitotic block, loss of cell adhesion and disrupted cytoskeletal structure in HT29 cells. Carcinogenesis 2004, 25, 1409-1415. [CrossRef] [PubMed]

274. Jackson, S.J.; Singletary, K.W. Sulforaphane inhibits human MCF-7 mammary cancer cell mitotic progression and tubulin polymerization. J. Nutr. 2004, 134, 2229-2236. [CrossRef]

275. Bryant, C.S.; Kumar, S.; Chamala, S.; Shah, J.; Pal, J.; Haider, M.; Seward, S.; Qazi, A.M.; Morris, R.; Semaan, A. Sulforaphane induces cell cycle arrest by protecting RB-E2F-1 complex in epithelial ovarian cancer cells. Mol. Cancer 2010, 9, 47. [CrossRef]

276. Lee, C.-S.; Cho, H.-J.; Jeong, Y.-J.; Shin, J.-M.; Park, K.-K.; Park, Y.-Y.; Bae, Y.-S.; Chung, I.-K.; Kim, M.; Kim, C.-H. Isothiocyanates inhibit the invasion and migration of $\mathrm{C} 6$ glioma cells by blocking FAK/JNK-mediated MMP-9 expression. Oncol. Rep. 2015, 34, 2901-2908. [CrossRef]

277. Tang, L.; Zhang, Y. Dietary isothiocyanates inhibit the growth of human bladder carcinoma cells. J. Nutr. 2004, 134, 2004-2010. [CrossRef]

278. Pledgie-Tracy, A.; Sobolewski, M.D.; Davidson, N.E. Sulforaphane induces cell type-specific apoptosis in human breast cancer cell lines. Mol. Cancer Ther. 2007, 6, 1013-1021. [CrossRef]

279. Xiao, D.; Powolny, A.A.; Singh, S.V. Benzyl isothiocyanate targets mitochondrial respiratory chain to trigger reactive oxygen species-dependent apoptosis in human breast cancer cells. J. Biol. Chem. 2008, 283, 30151-30163. [CrossRef] [PubMed]

280. Lu, Q.; Lin, X.; Feng, J.; Zhao, X.; Gallagher, R.; Lee, M.Y.; Chiao, J.W.; Liu, D. Phenylhexyl isothiocyanate has dual function as histone deacetylase inhibitor and hypomethylating agent and can inhibit myeloma cell growth by targeting critical pathways. J. Hematol. Oncol. 2008, 1, 6. [CrossRef] [PubMed]

281. Chen, H.; Lin, J.; Lin, Y.; Tsai, T.; Chou, K.; Hwang, T. 44 Allyl isothiocyanate induces reactive oxygen species-mediated autophagy through beclin-1 in human prostate cancer cells. Eur. Urol. 2016, 15, e44. [CrossRef]

282. Singh, S.V.; Srivastava, S.K.; Choi, S.; Lew, K.L.; Antosiewicz, J.; Xiao, D.; Zeng, Y.; Watkins, S.C.; Johnson, C.S.; Trump, D.L. Sulforaphane-induced cell death in human prostate cancer cells is initiated by reactive oxygen species. J. Biol. Chem. 2005, 280, 19911-19924. [CrossRef]

283. Kim, J.-H.; Xu, C.; Keum, Y.-S.; Reddy, B.; Conney, A.; Kong, A.-N.T. Inhibition of EGFR signaling in human prostate cancer PC-3 cells by combination treatment with $\beta$-phenylethyl isothiocyanate and curcumin. Carcinogenesis 2006, 27, 475-482. [CrossRef]

284. Gamet-Payrastre, L.; Li, P.; Lumeau, S.; Cassar, G.; Dupont, M.-A.; Chevolleau, S.; Gasc, N.; Tulliez, J.; Tercé, F. Sulforaphane, a naturally occurring isothiocyanate, induces cell cycle arrest and apoptosis in HT29 human colon cancer cells. Cancer Res. 2000, 60, 1426-1433. [PubMed]

285. Bhattacharya, A.; Li, Y.; Wade, K.L.; Paonessa, J.D.; Fahey, J.W.; Zhang, Y. Allyl isothiocyanate-rich mustard seed powder inhibits bladder cancer growth and muscle invasion. Carcinogenesis 2010, 31, 2105-2110. [CrossRef] [PubMed]

286. Cho, H.J.; Lim, D.Y.; Kwon, G.T.; Kim, J.H.; Huang, Z.; Song, H.; Oh, Y.S.; Kang, Y.-H.; Lee, K.W.; Dong, Z. Benzyl isothiocyanate inhibits prostate cancer development in the transgenic adenocarcinoma mouse prostate (TRAMP) model, which is associated with the induction of cell cycle G1 arrest. Int. J. Mol. Sci. 2016, 17, 264. [CrossRef] [PubMed]

287. Srivastava, S.K.; Xiao, D.; Lew, K.L.; Hershberger, P.; Kokkinakis, D.M.; Johnson, C.S.; Trump, D.L.; Singh, S.V. Allyl isothiocyanate, a constituent of cruciferous vegetables, inhibits growth of PC-3 human prostate cancer xenografts in vivo. Carcinogenesis 2003, 24, 1665-1670. [CrossRef] [PubMed]

288. Myzak, M.C.; Tong, P.; Dashwood, W.-M.; Dashwood, R.H.; Ho, E. Sulforaphane retards the growth of human PC-3 xenografts and inhibits HDAC activity in human subjects. Exp. Biol. Med. 2007, 232, 227-234.

289. Liang, H.; Lai, B.; Yuan, Q. Sulforaphane induces cell-cycle arrest and apoptosis in cultured human lung adenocarcinoma LTEP-A2 cells and retards growth of LTEP-A2 xenografts in vivo. J. Nat. Prod. 2008, 71, 1911-1914. [CrossRef] [PubMed]

290. Chung, F.-L.; Conaway, C.C.; Rao, C.; Reddy, B.S. Chemoprevention of colonic aberrant crypt foci in Fischer rats by sulforaphane and phenethyl isothiocyanate. Carcinogenesis 2000, 21, 2287-2291. [CrossRef] 
291. Boreddy, S.R.; Pramanik, K.C.; Srivastava, S.K. Pancreatic tumor suppression by benzyl isothiocyanate is associated with inhibition of PI3K/AKT/FOXO pathway. Clin. Cancer Res. 2011, 17, 1784-1795. [CrossRef]

292. Xu, C.; Huang, M.T.; Shen, G.; Yuan, X.; Lin, W.; Khor, T.O.; Conney, A.H.; Kong, A.N. Inhibition of 7,12-dimethylbenz(a)anthracene-induced skin tumorigenesis in C57BL/6 mice by sulforaphane is mediated by nuclear factor E2-related factor 2. Cancer Res. 2006, 66, 8293-8296. [CrossRef]

293. Hu, R.; Xu, C.; Shen, G.; Jain, M.R.; Khor, T.O.; Gopalkrishnan, A.; Lin, W.; Reddy, B.; Chan, J.Y.; Kong, A.-N.T. Gene expression profiles induced by cancer chemopreventive isothiocyanate sulforaphane in the liver of C57BL/6J mice and C57BL/6J/Nrf2 (-/-) mice. Cancer Lett. 2006, 243, 170-192. [CrossRef]

294. Gupta, P.; Adkins, C.; Lockman, P.; Srivastava, S.K. Metastasis of breast tumor cells to brain is suppressed by phenethyl isothiocyanate in a novel in vivo metastasis model. PLoS ONE 2013, 8, e67278. [CrossRef] [PubMed]

295. Aras, U.; Gandhi, Y.A.; Masso-Welch, P.A.; Morris, M.E. Chemopreventive and anti-angiogenic effects of dietary phenethyl isothiocyanate in an N-methyl nitrosourea-induced breast cancer animal model. Biopharm. Drug Dispos. 2013, 34, 98-106. [CrossRef] [PubMed]

296. Su, L.J.; Stahr, S.; Kadlubar, S.A.; Chiang, T.-C.; Wong, H.K. Tanning bed use, risk of melanoma and opportunity for prevention with sulforaphane. Transl. Cancer Res. 2016, 5, S944-S950. [CrossRef]

297. Ko, J.M.; Fisher, D.E. A new era: Melanoma genetics and therapeutics. J. Pathol. 2011, 223, 242-251. [CrossRef] [PubMed]

298. Shtivelman, E.; Davies, M.Q.; Hwu, P.; Yang, J.; Lotem, M.; Oren, M.; Flaherty, K.T.; Fisher, D.E. Pathways and therapeutic targets in melanoma. Oncotarget 2014, 5, 1701-1752. [CrossRef]

299. Hocker, T.L.; Singh, M.K.; Tsao, H. Melanoma Genetics and Therapeutic Approaches in the 21st Century: Moving from the Benchside to the Bedside. J. Investig. Dermatol. 2008, 128, 2575-2595. [CrossRef] [PubMed]

300. Sigalotti, L.; Covre, A.; Fratta, E.; Parisi, G.; Colizzi, F.; Rizzo, A.; Danielli, R.; Nicolay, H.J.; Coral, S.; Maio, M. Epigenetics of human cutaneous melanoma: Setting the stage for new therapeutic strategies. J. Transl. Med. 2010, 8, 56. [CrossRef]

301. Huang, S.; Hsu, M.; Hsu, S.; Yang, J.; Huang, W.; Huang, A.; Hsiao, Y.; Yu, C.; Chung, J. Phenethyl isothiocyanate triggers apoptosis in human malignant melanoma A375. S2 cells through reactive oxygen species and the mitochondria-dependent pathways. Hum. Exp. Toxicol. 2014, 33, 270-283. [CrossRef]

302. Fuke, Y.; Shinoda, S.; Nagata, I.; Sawaki, S.; Murata, M.; Ryoyama, K.; Koizumi, K.; Saiki, I.; Nomura, T. Preventive effect of oral administration of 6-(methylsulfinyl) hexyl isothiocyanate derived from wasabi (Wasabia japonica Matsum) against pulmonary metastasis of B16-BL6 mouse melanoma cells. Cancer Detect. Prev. 2006, 30, 174-179. [CrossRef]

303. Sasaki, T.; Kudoh, K.; Uda, Y.; Ozawa, Y.; Shimizu, J.; Kanke, Y.; Takita, T. Effects of isothiocyanates on growth and metastaticity of B16-F10 melanoma cells. Nutr. Cancer 1999, 33, 76-81. [CrossRef] [PubMed]

304. Hamsa, T.P.; Thejass, P.; Kuttan, G. Induction of apoptosis by sulforaphane in highly metastatic B16F-10 melanoma cells. Drug Chem. Toxicol. 2011, 34, 332-340. [CrossRef]

305. Thejass, P.; Kuttan, G. Allyl isothiocyanate (AITC) and phenyl isothiocyanate (PITC) inhibit tumour-specific angiogenesis by downregulating nitric oxide (NO) and tumour necrosis factor- $\alpha$ (TNF- $\alpha$ ) production. Nitric Oxide 2007, 16, 247-257. [CrossRef] [PubMed]

306. Sahu, R.P. Expression of the platelet-activating factor receptor enhances benzyl isothiocyanate-induced apoptosis in murine and human melanoma cells. Mol. Med. Rep. 2015, 12, 394-400. [CrossRef]

307. Lai, K.C.; Hsiao, Y.T.; Yang, J.L.; Ma, Y.S.; Huang, Y.P.; Chiang, T.A.; Chung, J.G. Benzyl isothiocyanate and phenethyl isothiocyanate inhibit murine melanoma B16F10 cell migration and invasion in vitro. Int. J. Oncol. 2017, 51, 832-840. [CrossRef]

308. Ma, Y.S.; Hsiao, Y.T.; Lin, J.J.; Liao, C.L.; Lin, C.C.; Chung, J.G. Phenethyl Isothiocyanate (PEITC) and Benzyl Isothiocyanate (BITC) Inhibit Human Melanoma A375.S2 Cell Migration and Invasion by Affecting MAPK Signaling Pathway In Vitro. Anticancer Res. 2017, 37, 6223-6234. [PubMed]

309. Rudolf, K.; Cervinka, M.; Rudolf, E. Sulforaphane-induced apoptosis involves p53 and p38 in melanoma cells. Apoptosis 2014, 19, 734-747. [CrossRef]

310. Mantso, T.; Sfakianos, A.P.; Atkinson, A.; Anestopoulos, I.; Mitsiogianni, M.; Botaitis, S.; Perente, S.; Simopoulos, C.; Vasileiadis, S.; Franco, R.; et al. Development of a Novel Experimental In Vitro Model of Isothiocyanate-induced Apoptosis in Human Malignant Melanoma Cells. Anticancer Res. 2016, 36, 6303-6309. [CrossRef] 
311. Huang, S.-H.; Wu, L.-W.; Huang, A.-C.; Yu, C.-C.; Lien, J.-C.; Huang, Y.-P.; Yang, J.-S.; Yang, J.-H.; Hsiao, Y.-P.; Wood, W.G. Benzyl isothiocyanate (BITC) induces G2/M phase arrest and apoptosis in human melanoma A375. S2 cells through reactive oxygen species (ROS) and both mitochondria-dependent and death receptor-mediated multiple signaling pathways. J. Agric. Food Chem. 2012, 60, 665-675. [CrossRef]

312. Mantso, T.; Anestopoulos, I.; Lamprianidou, E.; Kotsianidis, I.; Pappa, A.; Panayiotidis, M.I. Isothiocyanate-induced Cell Cycle Arrest in a Novel In Vitro Exposure Protocol of Human Malignant Melanoma (A375) Cells. Anticancer Res. 2019, 39, 591-596. [CrossRef]

313. Mitsiogianni, M.; Mantso, T.; Trafalis, D.T.; Vasantha Rupasinghe, H.P.; Zoumpourlis, V.; Franco, R.; Botaitis, S.; Pappa, A.; Panayiotidis, M.I. Allyl isothiocyanate regulates lysine acetylation and methylation marks in an experimental model of malignant melanoma. Eur. J. Nutr. 2019, 1-13. [CrossRef] [PubMed]

314. Caterina, M.J.; Pang, Z. TRP channels in skin biology and pathophysiology. Pharmaceuticals 2016, 9, 77. [CrossRef]

315. Oehler, B.; Scholze, A.; Schaefer, M.; Hill, K. TRPA1 is functionally expressed in melanoma cells but is not critical for impaired proliferation caused by allyl isothiocyanate or cinnamaldehyde. Naunyn-Schmiedeberg's Arch. Pharmacol. 2012, 385, 555-563. [CrossRef]

316. Khoobchandani, M.; Ganesh, N.; Gabbanini, S.; Valgimigli, L.; Srivastava, M. Phytochemical potential of Eruca sativa for inhibition of melanoma tumor growth. Fitoterapia 2011, 82, 647-653. [CrossRef]

317. Bansal, P.; Medhe, S.; Ganesh, N.; Srivastava, M. In vitro anticancer activity of dietary bioagent (isothiocyanates) on HepG2 and B16F10 cell lines: A comparative study. Annals Plant Sci. 2013, 2, 234-237.

318. Fisher, M.L.; Adhikary, G.; Grun, D.; Kaetzel, D.M.; Eckert, R.L. The Ezh2 polycomb group protein drives an aggressive phenotype in melanoma cancer stem cells and is a target of diet derived sulforaphane. Mol. Carcinog. 2016, 55, 2024-2036. [CrossRef] [PubMed]

319. Arcidiacono, P.; Stabile, A.M.; Ragonese, F.; Pistilli, A.; Calvieri, S.; Bottoni, U.; Crisanti, A.; Spaccapelo, R.; Rende, M. Anticarcinogenic activities of sulforaphane are influenced by Nerve Growth Factor in human melanoma A375 cells. Food Chem. Toxicol. 2018, 113, 154-161. [CrossRef]

320. Bansal, P.; Medhe, S.; Ganesh, N.; Srivastava, M.M. Antimelanoma Potential of Eruca sativa Seed Oil and its Bioactive Principles. Indian J. Pharm. Sci. 2015, 77, 208-217. [CrossRef] [PubMed]

321. Ni, W.Y.; Lu, H.F.; Hsu, S.C.; Hsiao, Y.P.; Liu, K.C.; Liu, J.Y.; Ji, B.C.; Hsueh, S.C.; Hung, F.M.; Shang, H.S.; Chung, J.G. Phenethyl isothiocyanate inhibits in vivo growth of subcutaneous xenograft tumors of human malignant melanoma A375.S2 cells. In Vivo 2014, 28, 891-894.

322. Ni, W.-Y.; Hsiao, Y.-P.; Hsu, S.-C.; Hsueh, S.-C.; Chang, C.-H.; Ji, B.-C.; Yang, J.-S.; Lu, H.-F.; Chung, J.-G. Oral administration of benzyl-isothiocyanate inhibits in vivo growth of subcutaneous xenograft tumors of human malignant melanoma A375. S2 cells. In Vivo 2013, 27, 623-626.

323. Manesh, C.; Kuttan, G. Effect of naturally occurring allyl and phenyl isothiocyanates in the inhibition of experimental pulmonary metastasis induced by B16F-10 melanoma cells. Fitoterapia 2003, 74, 355-363. [CrossRef]

324. Thejass, P.; Kuttan, G. Modulation of cell-mediated immune response in B16F-10 melanoma-induced metastatic tumor-bearing C57BL/6 mice by sulforaphane. Immunopharmacol. Immunotoxicol. 2007, 29, $173-186$. [CrossRef] [PubMed]

325. Pradhan, S.J.; Mishra, R.; Sharma, P.; Kundu, G.C. Quercetin and sulforaphane in combination suppress the progression of melanoma through the downregulation of matrix metalloproteinase-9. Exp. Ther. Med. 2010, 1, 915-920. [CrossRef] [PubMed]

326. Do, D.; Pai, S.; Rizvi, S.A.; D'Souza, M.J. Development of sulforaphane-encapsulated microspheres for cancer epigenetic therapy. Int. J. Pharm. 2010, 386, 114-121. [CrossRef] [PubMed]

327. Nguyen, N.; Sharma, A.; Nguyen, N.; Sharma, A.K.; Desai, D.; Huh, S.J.; Amin, S.; Meyers, C.; Robertson, G.P. Melanoma chemoprevention in skin reconstructs and mouse xenografts using isoselenocyanate-4. Cancer Prev. Res. 2011, 4, 248-258. [CrossRef] [PubMed]

328. Sharma, A.K.; Sharma, A.; Desai, D.; Madhunapantula, S.V.; Huh, S.J.; Robertson, G.P.; Amin, S. Synthesis and anticancer activity comparison of phenylalkyl isoselenocyanates with corresponding naturally occurring and synthetic isothiocyanates. J. Med. Chem. 2008, 51, 7820-7826. [CrossRef] [PubMed] 
329. Sharma, A.; Sharma, A.K.; Madhunapantula, S.V.; Desai, D.; Huh, S.J.; Mosca, P.; Amin, S.; Robertson, G.P. Targeting Akt3 signaling in malignant melanoma using isoselenocyanates. Clin. Cancer Res. 2009, 15, 1674-1685. [CrossRef]

330. Sk, U.H.; Gowda, A.P.; Crampsie, M.A.; Yun, J.K.; Spratt, T.E.; Amin, S.; Sharma, A.K. Development of novel naphthalimide derivatives and their evaluation as potential melanoma therapeutics. Eur. J. Med. Chem. 2011, 46, 3331-3338. [CrossRef] 